\title{
Akut Şok ve Kronik Stresler Karşısında Kentsel Dayanıklılık \& Sürdürülebilir Dayanıklılık Yaklaşımı
}

\author{
Betül ERGÜN KONUKCU ${ }^{1}$
}

\section{Öz}

Kentlerin; çözülmesi gereken meseleleri halletmesi, gelişimi önünde engel oluşturan bariyerleri aşması ve sorun temelli riskleri yönetmesi sürdürülebilir gelişimi için çok önemlidir. Ne ile baş etmek zorunda olduğunu bilen ve ne ye karşı dayanıklı olması gerektiğini öngören kentler, geleceklerini tercihleri doğrultusunda şekillendirip, olması gerektiği gibi yönlendirebilir. Afet tehlikeleri (doğa olayları ve iklim değişikliği kaynaklı vb.) ile birlikte; sorumsuz kentleşmenin getirdiği sonuçlar (doğal kaynakların bilinçsizce tüketilmesi, enerji kullanımı, karbon emisyon vb.), kalkınma önünde engel oluşturan sosyoekonomik ve kültürel stresler (yoksulluk, eşitsizlik, adaletsizlik, güvenlik, gelir azalması vb.) ve çevre ile ilgili problemler (çevresel degredasyon, kirlilik, biyoçeşitliliğin azalması, ekosistem kaynak azalması vb.) kentleri baskılayan önemli sorunların ana başlıklarından sadece bazılarıdır. Bu sorunlardan kenti tehdit eden, beklenen ancak tam zamanı belli olmayan, aniden gelişen ve öngörülemeyen sorunlar akut şok, kentin dokusunu zayıflatan ve süreçte hala çözüm bulunamayan sorunlar kronik stress olarak adlandırıır. Deprem, salgın hastalık, siber sadırı vb. sorunlar akut şoklara örnek iken, trafik, beyin göçü, işsizlik, kıtlık, su sıkıntısı vb. sorunlar kentlerin karşı karşıya olduğu kronik streslere örnektir. Bu sorunlar kentleri geleceğe taşımanın önünde büyük bir tehdittir. Kentler sürdürülebilir gelişimi için; sorunları karşısında kentsel dayanıklıı̆̆ını inşa etmek zorundadır. "Kentsel Dayanıkııı" kent bileşenlerinin, sektörlerin, sistemlerin ve kent paydaşlarının, mevcut ve olası akut şok \& kronik stresler ile baş edebilme gücü ve kapasitesi olup, sürdürülebilir gelişimi için kentlerin oluşturduğu savunma mekanizmasıdır. Değişen, farklılaşan, güçlenen, çeşitlenen, beklenen ve öngörülemeyen küresel ve yerel sorunlar karşısında; dayanıklı olma, hayatta kalma, çabuk toparlanma, etkilerini absorbe etme, getirdiği değişimlere adapte olabilme, normal şartlara gelişerek dönebilme ve gerektiğinde dönüşebilme yeteneğinin kent bütününe yani kent paydaşlarına, kent bileşenlerine, kentsel sektörler ve sistemlere kazandırılması kentsel dayanıklılık için çok önemlidir. Kentlerin gelecekte ne ile ne zaman karşılaşacağını bilmek imkânsızdır. Akut şoklar ve kronik stresler karşısında daha güçlü, iyi korunan, güvenli, yaşanabilir ve sürdürülebilir bir kent; sürdürülebilir dayanıklıık yaklaşımı çerçevesinde kent bütününe kentsel dayanıklılık yeteneğinin kazandırıması ile mümkün kılınabilir. Sürdürülebilir Dayanıklılık Yaklaşımının kent bütününe entegre edilmesinin yollarından biri "Kentsel Dayanıklılık Ofis'inin kurulmasıdır.

Anahtar Kelimeler: Kentsel sorunlar, akut şok, kronik stres, dayanıklılık, kentsel dayanıkııık, sürdürülebilir dayanıkııık

\footnotetext{
${ }^{1}$ Deprem ve Zemin İnceleme Müdürlüğü, İstanbul Büyükşehir Belediyesi

*ilgiliyazar / Corresponding author: betulergun_77@hotmail.com, betul.konukcu@ibb.gov.tr GönderimTarihi / Submission Date: 18.09.2020

Kabul Tarihi / Acception Date: 07.12.2020
} 


\title{
Urban Resilience Against to Acute Shocks and Chronical Stresses \&Sustainable Resilience Approach
}

\begin{abstract}
To maintain the sustainable development of cities, it is significantly essential to solve immediate concerns, overcome barriers against development and manage the risks based on challenges. The cities that know to deal with the challenges and anticipate how to make theirselves resilient can develop their future according to their preferences and administer them as they should. Not only disaster risks (based on natural hazards and climate change) but also consequences of irresponsible urbanization (unconscious consumption of natural resources, energy use, carbon emission etc.), socio-economic and cultural stresses that impede development (poverty, inequality, injustice, security, income reduction, etc.) and environmental problems (environmental degredation, contamination, bio-diversity loss, ecosystem resource reduction etc.) significantly affect urban resilience and sustainability. These complications are called acute shocks and chronical stressess. Acute shocks are unpredictable and abruptly strikes the cities like earthquake, pandemic, cyber attack etc. Chronical stress are unsolved, permanent problems in daily life like traffic, brain drain, drought, unemployment, water shortage etc. These challenges are serious threats to carve out a better future for cities. In the manner of sustainable development it necessary to build urban resilience against to acute shocks and chronical stress. Urban Resilience is the coping skill and capacity to cope with acute shocks and chronical stressrss. Urban resilience is a systematic and dynamic process that built in time, requires qualitative and quantitative development in the intangible and tangible urban characters and transform in compulsory situations. Urban resilience is empowering cities in face of the different factors currently threatening their future development. For building skills such as be strength, swift recovery, survival, absorbing capacity, adaptation, transformation to all city (urban components, sectors, systems, stakeholders) against the changing, differentiating, strengthening, diversifying, potential and unanticipated global and local problems is necessary and important for cities in order to cope with challenges and to be sustainable resilience. In the feature, beyond the realm of possibility to know, when and what challenges will the cities face with. Enhancing cities capacity, making safer and more resilient to deal with the heterogeneous factors currently threatening them and unforeseen challenges depends on todays' decisions, actions and applications. Stronger, well protected and swift recovery cities against the acute shocks and chronical stresses are the investment for safe, liveable and sustainable cities. This investment can only be made possible by providing urban resilience capability to the whole city within the framework of sustainable resilience approach. One of the ways to integrate the Sustainable Resilience Approach to the entire city is to set up an Urban Resilience Office.
\end{abstract}

Keywords: Urban challenges, acute shocks, chronical stress, resilience, urban resilience, sustainable resilience

\section{GiRiş}

Dünyamız giderek kentleşmektedir. Giderek artan nüfus; sınırlı kaynak ve kapasiteye sahip kentler üzerinde ciddi bir baskı uygulamaktadır. Kaynakları hızla tükenen, kapasitesi zorlanan ve zaman zaman yeterli gelmeyen dünya kentleri aynı zamanda hem yerel hem de küresel sorunların tehdidi altındadır.

1950'li yılların başında dünya nüfusu yaklaşık 2,6 milyar iken günümüzde bu sayı neredeyse 7,8 milyara ulaşmıştır (URL1). Geçmişten bugüne nüfus artışına paralel; kentlerde yaşayan 
insan sayısı da gittikçe yükselmiştir. 1950'li yılların başında dünya nüfusunun sadece \%30'u kentlerde yaşarken, bu yüzde 2010 yılların sonunda 2019 yılında \%56'yı geçmiştir(URL1). Yapılan çalışmalar; gelecek yıllarda da insanların çoğunlukla kentlerde yaşamayı tercih edeceğini göstermektedir. Birleşmiş Milletler Ekonomik ve Sosyal İşler Dairesi'nin çalışmasına göre, 2050 yılında dünya nüfusunun \%68'i kentlerde yaşamlarını sürdürecektir (UN1) (Şekil 1).

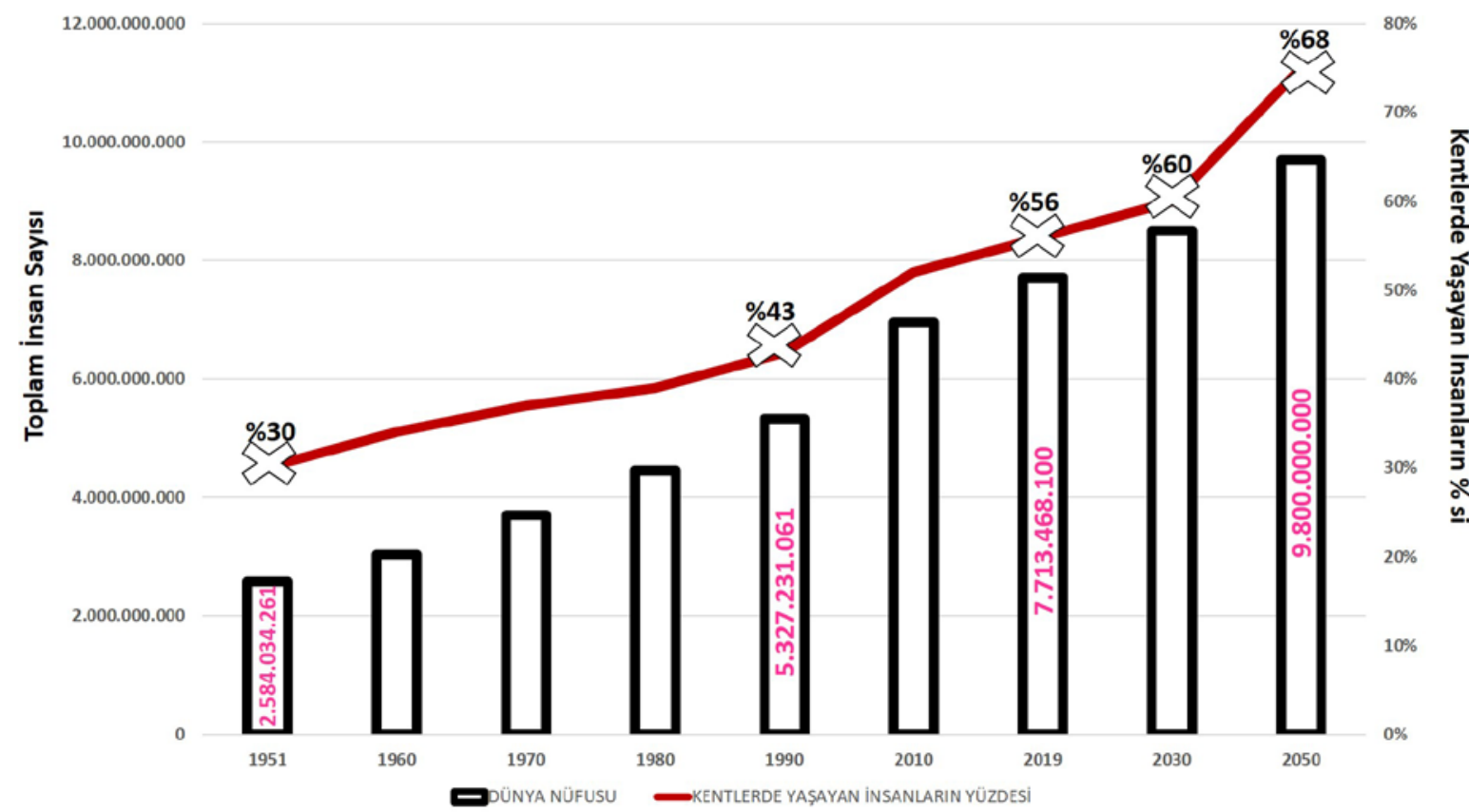

Şekil 1. Dünyamız kentleşiyor

Kentler artan nüfusu ile birlikte, giderek çoğalan problemlerle de karşı karşıya kalmaktadır. Kentlerin; çözülmesi gereken meseleleri halletmesi, gelişimi önünde engel oluşturan bariyerleri aşması ve sorun temelli riskleri yöneterek azaltması, sürdürülebilir gelişimi için çok önemlidir. Sorunlarını bilen ve öngören kentler; katılımcı ve kapsayıcı yaklaşım, efektif ve güçlü strateji, doğru karar, risk azaltma çalışmaları, uygulanabilir yatırım programları, disiplinler üstü çalışma, gerekli uygulamalar ve yönetilebilir sistemler sayesinde, sorunlar karşısında baş edebilme gücünü arttırarak geleceklerine sahip çıkabilirler.

\section{KENTSEL SORUNLAR: AKUT ŞOKLAR VE KRONIK STRESLER}

Kentler; değişen, farklılaşan, güçlenen, çeşitlenen, beklenen ve öngörülemeyen küresel ve yerel sorunlar ile baş etmek zorundadır.

Doğa olayları ( deprem, sel, heyelan, yangın, volkanik aktivite vb.) ve iklim değişikliği ( kuraklık, fırtına, deniz suyu yükselmesi, şiddetli yağış, aşırı sıcak ve soğuk havalar) kaynaklı afet tehlikeleri ve kenti oluşturan unsurlar (fiziksel yapı, doğal çevre, sosyal doku ve ekonomik durum) üzerinde neden olduğu riskleri ile birlikte; sorumsuz kentleşmenin getirdiği sonuçlar (doğal kaynakların bilinçsizce tüketilmesi, enerji kullanımı, karbon emisyon vb.), kalkınma önünde engel oluşturan sosyoekonomik kültürel stresler (yoksulluk, eşitsizlik, adaletsizlik, güvenlik, gelir azalması vb.) ve çevre sorunları (çevresel degredasyon, kirlilik, biyoçeşitliliğin azalması, ekosistem kaynak azalması vb.) kentleri baskılayan önemli sorunların ana başıklarıdır (Şekil 2). 


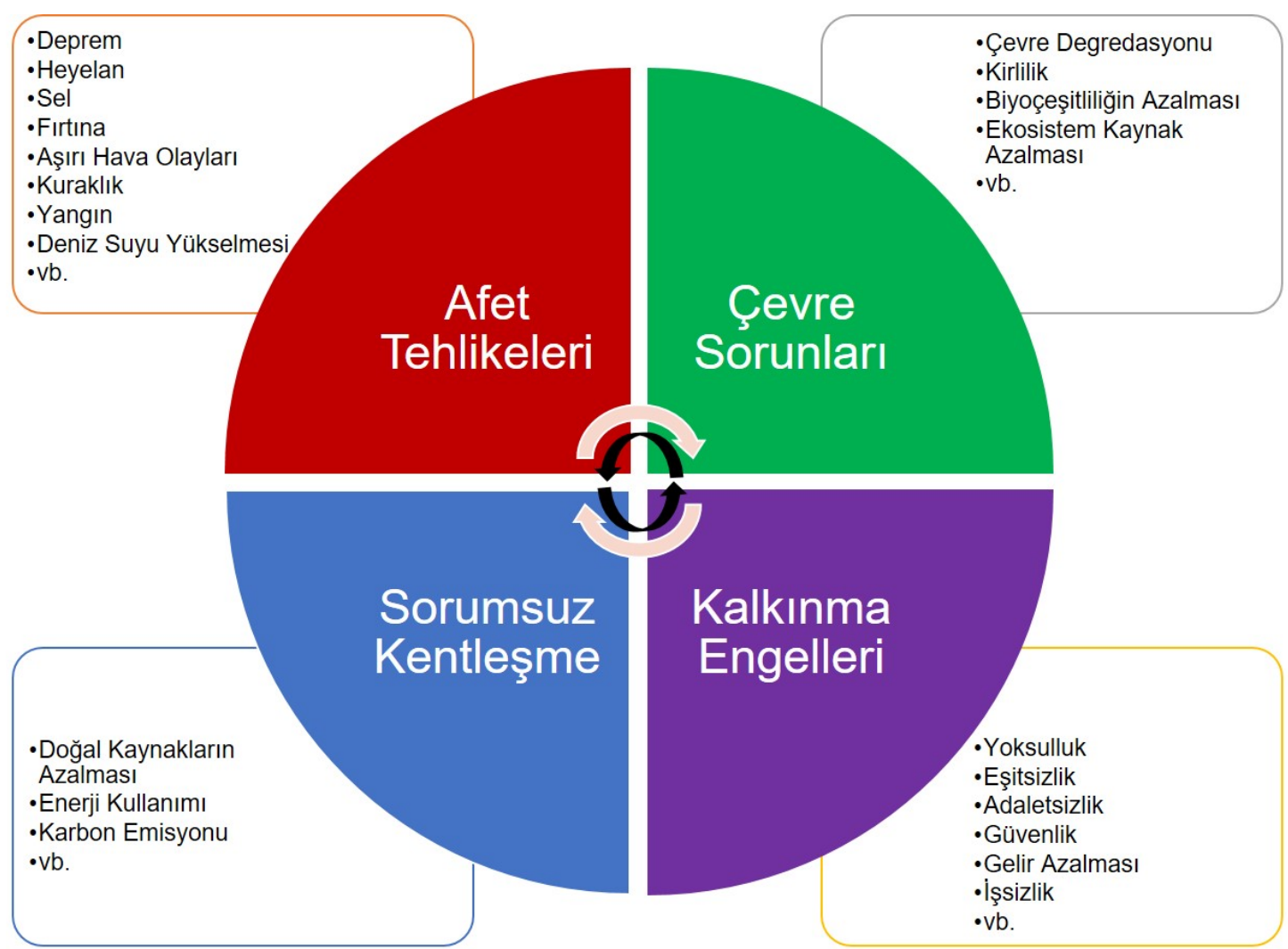

Şekil 2. Kent ana sorun başlıkları

Doğa ve iklim olayları kaynaklı afetler; kentlerin fiziksel, sosyal, ekonomik, tarihi ve kültürel yapısının varlığı ve sürdürülebilirliği için büyük bir tehdittir. Dünya Ekonomik Formu'nun 2020 için öngördüğü dünya için küresel olası risk sıralamasının ilk 3 sırasını aşırı hava olayları, iklim eylemlerinde başarısızlık ve doğal afetler paylaşmaktadır (WEF). Geçtiğimiz 2000 2019 yılları arasında dünya genelinde 7348 afet (sel, fırtına, deprem, aşırı sıcaklık, heyelan, kuraklık, yangın, volkanik aktivite ve kütle hareketlerinden kaynaklı) yaşanmış, bu afetler ortalama 4 milyar insanı etkilemiş, yaklaşık 1.23 milyon insanın hayatını kaybetmesine sebep olmuş ve ekonomik olarak 2.97 trilyon US \$ kayıp oluşturmuştur (CRED, UNDRR, 2020). Bu maddi ve manevi ciddi kayıplara rağmen; afet riski altındaki kentlerin nüfusu hızla artmaya devam etmektedir. Dünya genelinde nüfusu 500.000 i geçen 1146 kent; siklon, sel, kuraklık, deprem, heyelan ve volkanik aktiviteden kaynaklı, en az 1 afeti geçmişinde tecrübe etmiş, yine en az 1 afet riskini geleceğinde yönetmek zorundadır (UN2) (Şekil 3). Afet risklerinin azaltılması, kentlerin geleceği için en temel hedeflerden bir tanesidir. Önlem alınmadığı takdirde doğa ve iklim değişikliği kaynaklı afet tehlikeleri; bir tehdit unsuru olarak önümüzdeki yıllarda da, can ve mal kayıplarına, ekonomik zararlara, çevre ve doğa tahribatına sebep olmaya devam edecektir. 


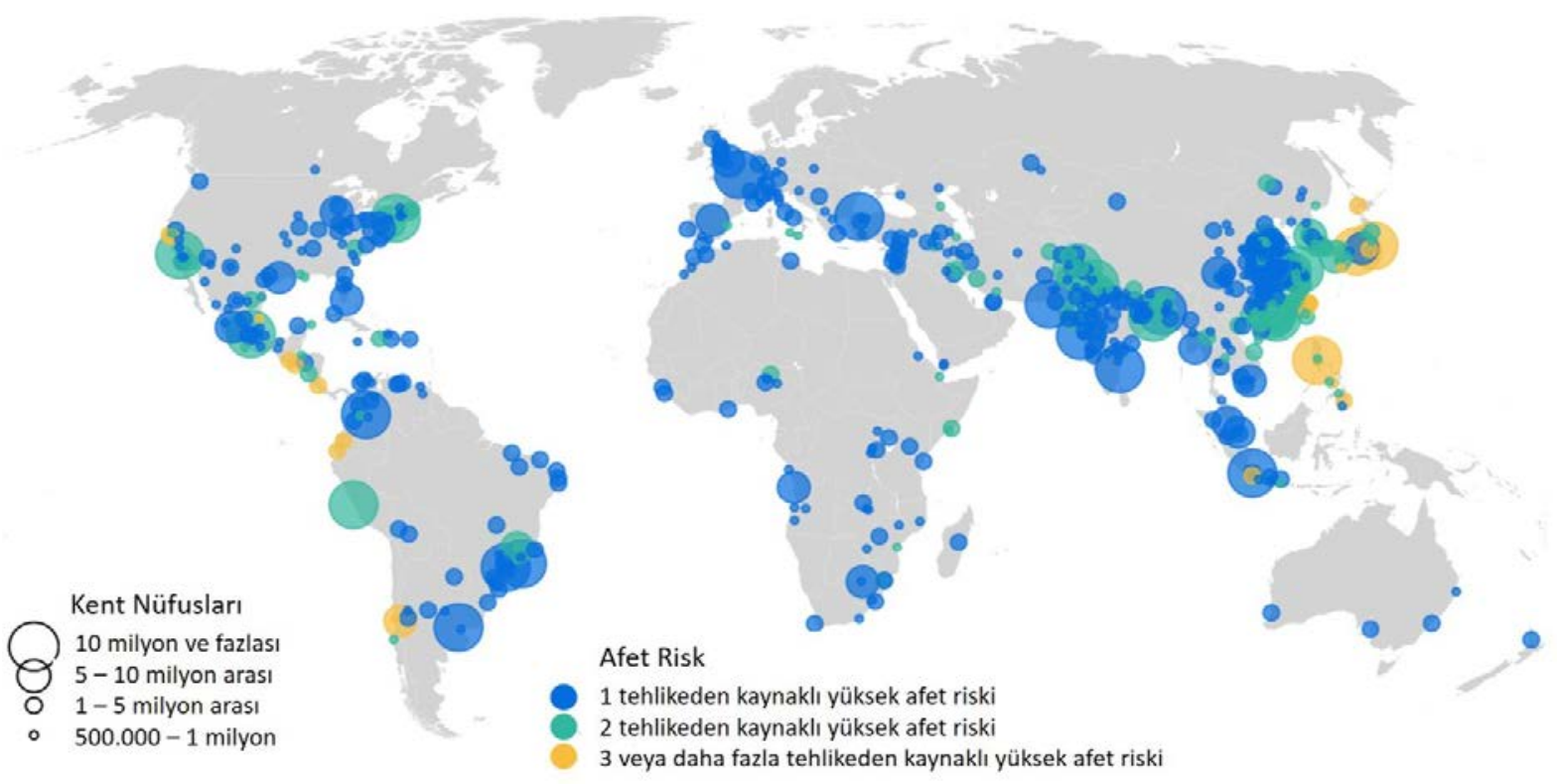

Şekil 3. Afet riskli altındaki kalabalık kentler (UN2, 2018)

Değişen alışkanlıklarımız, yanlış tercihlerimiz ve kentleşme sorunlarımız; afet riskinin yanında kentleri birçok sorun ile karşı karşıya bırakmıştır. Birleşmiş Milletler Çevre ve Kalkınma Programları verilerine göre; günümüzde $\% 56$ oranı ile kentlerde yaşama tercihi ya da mecburiyeti; kentleri \% 75 oranla doğal kaynakların tüketilmesinden (URL2), \% 60 - 80 oranla enerji kullanımından (URL3), sorumlu hale getirmiştir.

Doğal kaynakların tüketilmesinde en önemli problemlerden biri su sıkıntısıdır. Dünya yüzölçümünü yaklaşık $\% 70$ oranla su ile çevrili olmasına rağmen bu oranın sadece $\% 1{ }^{\prime} i$ insanların kullanımına uygun tatlı sudur (UNCDD1). Tatlı su kaynakları ne yazık ki giderek tükenmektedir. Su kullanımı 1980'lerden günümüze; sosyo-ekonomik gelişmeler, nüfus artışı ve değişen tüketim alışkanlıklarından dolayı yılda yaklaşık \%1 oranında artmıştır. Su kullanım seviyesinin 2050 yılına kadar aynı oranda artışla; \%20 ila \%30 oranında artması beklenmektedir (UN WATER, UNESCO, 2019). Dünya genelinde; su güvencesizliği ve kaynak sıkıntısı probleminin yanında su talebin giderek artması, su kaynaklarının yeterliliği ve sürdürülebilirliği adına kentlerin gelecekleri için su tüketimi ile ilgili biran önce alması gereken tedbirlerin önemini ortaya ciddiyetle koymaktadır.

Bir diğer önemli doğal kaynak kaybı verimli toprak kaybıdır. Birleşmiş Milletler Çölleşme ile Mücadele Sözleşmesi (UNCDD2) kapsamında 2019 yılında yayınlanan raporda; kentleşmenin 2000 - 2030 yılları arasında dünya genelinde her yıl ortalama 16.000 ila $30.000 \mathrm{~km}^{2}$ 'lik birinci derece tarım arazisinin kaybedilmesine neden olduğu ve olacağı öngörülmektedir (UNCCD2). Bununla birlikte; Birleşmiş Miletlerin projeksiyonuna göre 2050 yılında dünya nüfusu yaklaşık 9,8 milyara ulaşacaktır. (URL4). Nüfus artışı ile birlikte, yiyecek talebinin de günümüze oranla \%60 oranında artacağı öngörülmektedir (URL5) . Dünyamızın var olan imkânları ile 2050 yılında yaklaşık 10 milyar insanı beslemek zorunda olacaktır. Artacak gıda talebine karşın; her yıl hektarlarca verimli alanın kentleşme, erozyon, ormansızlaşma, çoraklaşma, yanlış kullanım vb. nedenlerden kaynaklı yok olması; önümüzdeki yılların en önemli sorunlarından biri gıda güvencesizliğine çözüm getirilmesi adına şimdiden atılması gereken adımlar için çok vurucu bir nedendir.

Dünya genelinde tüketilen enerjinin sadece \% 20'si yenilenebilir enerji kaynaklarından sağlanmaktadır (URL6). Geri kalan enerji kaynakların büyük çoğunluğu fosil yakıtlardan elde edilmektedir. Worldometer verilerine göre petrol için kalan rezerv bilgisi yaklaşık $45 \mathrm{yıl}$, doğal 
gaz için ise yaklaşık 159 yıl yani ortalama 2 nesildir (URL7). Yani doğaya olumsuz etkisinin yanında enerji intiyacımızın büyük bir oranla karşılandığı bu enerji kaynakları zamanla tükenecektir. Bununla birlikte; 2030 a kadar küresel enerji talebinin $\% 40$ ila $\% 50$ oranında artacağı tahmin edilmektedir. Fosil yakıt kullanımının iklim sistemine kötü etkisi yanında rezervlerinin zaman ile azalacak olması ve küresel enerji talebinin giderek artması göz önüne alındığında; kentlerin doğaya zarar vermeyen yenilenebilir enerji sistemleri ile ilgili çalışmalarını biran önce hızlandırılması ve enerji kaynaklarını yenilebilir enerji kaynaklarına vakit geçirmeden dönüştürmesi çok önemlidir.

Son yıllarda kentler iklim değişikliği kaynaklı sorunlarla; çok sık, aniden ya da kronikleşmiş şekilde yüzleşmek zorunda kalmış ve kalmaya devam etmektedir. Ekstrem hava koşullarının (aşırı sıcak ve soğuk havalar, şiddetli yağışlar vb.) artması yanında, fırtınalar, su kıtlığı, kuraklık, deniz buzullarındaki incelme, deniz su seviyesinin yükselmesi iklim krizinin neden olduğu olumsuzluklardan sadece bazılarıdır. İklim değişikliğinin başlıca sebeplerinden biri olan karbon emisyonundan \%70 oranla kentler sorumludur (URL8). Karbon emisyonunun artması atmosferin ısısının yükselmesine yani küresel ısınmaya sebep olmaktadır. Küresel ısınma dünyadaki yaşamın sürdürülebilirliği için çoktan büyük bir tehdit olmaya başlamıştır. Okyanuslar yapıları gereği; iklim sistemindeki fazla ısının \%90'ını, insan eli oluşan karbondioksit miktarının ise \%30'unu absorbe edebilmektedir (URL9, URL10). Sanayi devriminin başlangıcından itibaren insan aktiviteleri; okyanuslar ve kriyosfer dâhil olmak üzere iklim sistemini büyük ölçüde olumsuz olarak etkilemiştir (IPCC). Bu aktiviteler sonucunda, okyanuslar giderek Isınmakta, asit oranı artmakta ve oksijen miktarı düşmektedir. Okyanuslardaki asit miktarı bu süreçte \%26 oranında artmıştır (URL10). Bu durum okyanus canlılarının biyoçeşitliliği ve ilgili besin zinciri için büyük bir tehdit oluşmaya devam etmektedir. Bir an önce gerekli tedbirler alınmaz ise; insan faaliyetlerinden giderek artan bir yüzde ile etkilenen okyanuslar; küresel ısınma karşısında tampon olma görevini yerine getiremeyecektir.

İklim krizi olumsuz etkisini baskın bir şekilde göstermeye devam ederken, kentli de bir şekilde çevresine zarar vermeye devam etmektedir. Çevresel degredasyon, kirlilik (hava, su, toprak, ışık, gürültü), biyo çeşitliliğin azalması, doğal kaynakların bilinçsizce tüketilmesi, verimli toprakların kaybı, çölleşme, ormanların yok edilmesi mevcut ve gelecek yaşamın en büyük problemlerindendir. Birleşmiş Milletlerin verilerine göre; 31.000'in üzerinde tür, neslinin tükenmesi tehlikesi altında olup, 2015 ve 2020 yılları arasında dünya genelinde her yıl yaklaşık 10 milyon hektar orman alanının tahrip edildiği ve edilmeye devam ettiği bilinmektedir (URL11). 2016 yılında hava kirliliği sebebi ile 4,2 milyon insan hayatını kaybetmiştir (URL12). Tercihleri doğrultusunda çevresine zarar veren insanoğlu tercihlerini değiştirmediği takdir de ne yazık ki seçimlerinin kötü sonuçlarına katlanmak zorunda kalacaktır.

Kentlerde yaşam tercihi ya da yaşama zorunluluğu; yaşam kalitesi açısından ne yazık ki her kentliye her fırsatı aynı derecede sunmamaktadır. Dünya genelinde 2018 yılında gecekondu ve kentin fakir semtlerinde yaşayan kentsel nüfusun oranı \%24'e yükselmiştir. (URL12). Yoksulluk, eşitsizlik, adaletsizlik, güvenlik problemleri, işsizlik, sağlık servislerinden faydalanma ve eğitim hizmetlerine erişim dünya genelinde kentlerin kentlisi için başarmak zorunda olduğu önemli sınavları haline gelmiştir.

Bir diğer önemli kent sorunu; zorunlu insan hareketidir. Birleşmiş Milletler Mülteciler Yüksek Komiserliği (UNHCR) verilerine göre 2019 yılı sonu itibari ile dünya genelinde yaklaşık 79,5 milyon insan evlerini zorla terk etmek zorunda kalmıştır (URL13). UNHCR; bu insanların yaklaşık 45,7 milyonunun kendi ülkeleri içinde yer değiştirmiş olduğunu, yaklaşık 26 milyonunun mülteci, 4,2 milyonunun ise sığınmacı olarak yaşamlarına devam ettiğini söylemektedir. UNHCR verilerine göre geri kalan yaklaşık 3,6 milyon kişi ise ülkesini terk 
eden Venezüella vatandaşıdır (URL13). Kentler; zulüm, savaş, ekonomik vb. sebeplerden dolayı vatanlarından ayrılan ve yeni vatan arayışı içine giren bu insanlar ve gelecekte olası ve öngörülemeyen sorunlar karşısında yaşam alanlarını değiştirecek potansiyel nüfus için; afet riski ve sürdürülebilir kaynak yönetimi için mutlaka bir strateji geliştirmelidir.

Günümüz trendi akıllı kentler yaratmak hedefinde ilgili tüm teknolojik gelişmelerin kent yaşamına entegre edilmesi; internet kullanımının hayatımızın ve işimizin önemli bir parçası olması, büyük veri ve bulut bilişim kullanımlarının artması; kentleri siber saldırılar karşısında açık hedef haline getirmiştir. Bundan dolayı siber saldıılar karşısında; siber güvenlik kentlerde ilgili tüm sistemlerin işlevselliğinin devamlılığı için çok önemlidir.

Tarihsel arşivlere baktığımızda geçmişten günümüze; salgın hastalıkların (Veba ve kolera salgınları, İspanyol gribi, HIVIAIDS, Ebola, SARS vb.) küresel olarak insanlığın ve kentlerin maruz kaldığı en ciddi sorunlardan biri olduğu görülmektedir. Bir salgın hastalığın önce kent içine sonra diğer kentler ve ülkelere yayılması bu denli hareketliğe sahip dünyamızda çok olasıdır. Buna en iyi örnek; 2020 yılının en önemli sorunu Covid19 salgın hastalığının Çin'in Wuhan kentinden başlayıp dünya geneli yayılmasıdır. Dünya Sağlık Örgütü tarafından 11 Mart 2020 tarihinde pandemi ilan edilen Covid19 hastalığına, 12 Kasım 2020 tarihi itibari ile dünya genelinde 51.848.261 kişi yakalanmış ve bu hastalıktan 1.280 .868 kişi hayatını kaybetmiştir (URL14). Küresel ve yerel tecrübeler salgın hastalıkların; kent ve insan yaşamını değişime zorlandığını göstermiştir. Bununla birlikte kimi kentlerin; sahip olduğu sağlık sistemlerinden dolayı küresel salgın hastalık ile baş edemedikleri, mevcut ekonomik sistemleri içinde yeterli önlemleri alamadıkları ve alternatif senaryolar geliştiremedikleri için ekonomik olarak zorlandıkları görülmüştür. Salgın hastalıklara karşı kentlerin biran önce yerel ve küresel olarak stratejiler geliştirmeleri ve çözüm için birlikte hareket etmeleri gerekmektedir.

Görüldüğü üzere; dünya kentleri; çeşitli olumsuzluklar, aşılamayan meseleler, önlenemeyen sorunlar, yerel ve küresel kırılganlıklar, ani şoklar ve kronikleşen problemler ile baş etmek zorundadır. Kentleri baskılayan; mevcut, olası, beklenmedik, öngörülemeyen, yavaşça gelişen, doğa kaynaklı veya insan eli ile oluşan, sıklıkla veya nadir olarak karşılaşılan bu sorunlardan; kenti tehdit eden; beklenen ancak tam zamanı belli olmayan, aniden gelişen ve öngörülemeyen sorunlar akut şok, kentin dokusunu zayıflatan ve süreçte hala çözüm bulunamayan sorunlar kronik stress olarak adlandırıır. Deprem, salgın hastalık, siber sadırı vb. akut şoklara örnek iken, trafik, beyin göçü, işsizlik, kıtlık, su sıkıntısı vb. kentlerin karşı karşıya olduğu kronik streslere örnektir. Bu sorunlar kentleri geleceğe taşımanın önünde büyük bir tehdittir (Şekil 4).

\footnotetext{
Deniz Suyu Seviyesinde Yükselme Toplu Taşımada Yetersizlik Nüfus Artışı Sosyal Konut Eksikliği Aşırı Sıcak ve Soğuklar Eğitimde Eksiklikler Beyin Göçü Trafik Fırtına, Tayfun, Siklon Sağılıta Eksiklikler Çamur Akması Su Güvencesizliği Su Baskını Yaşlanan Nüfus Çevre Degredasyonu Deprem Tsunami Suç ve Şiddet Ekolojik Dengenin Bozulması Heyelan Eşitsizlik Yangın Salgın Hastalık Doğal Kaynakların Hızla Tükenmesi

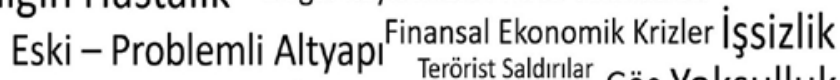
Biyoçeşitliliğin Azalması İklim Değişikliği Göç Yoksulluk Zorunlu İnsan Hareketi Gıda Güvensizliği Endüstriyel Kazalar Enerji Bağımlıı̆ğ Kirlilik (Su, Hava, Deniz, |şık, Ses)Ekonomik Eşitsizlik Şiddetli Yağış - Kent Selleri Siber Saldırı

Şekil 4. Kentleri tehdit eden akut şok ve kronik stresler
} 
Akut şok ve kronik streslere rağmen kentleri geleceğe taşımak; afet risklerini azaltarak, kalkınmayı engelleyen sorunlarını çözerek, iklim değişikliği sebeplerini azaltarak, kentlisi için yaşam kalitesini yükselterek aynı zamanda çevreyi ve doğayı koruyarak sağlanır. Bu süreçte yerel sorunlara; ilgili kent paydaşları ile birlikte çözüm üretmek ve küresel sorunlar için diğer dünya kentleri ile birlikte hareket etmek çok önemlidir. Kentler sürdürülebilir gelişimi için; akut şok ve kronik stresler karşısında kentsel dayanıklılığını (urban resilience) inşa etmek zorundadır.

\section{KENTSEL DAYANIKLILIK}

"Resilience" (dayanıklılık) kavramı geçmişten günümüze; hukuktan, siyasete, psikolojiden, toplumsal araştırmalara, mekanikten imalata, antropolojiden ekolojiye, afetten sürdürülebilirliğe kadar birçok disiplinde ve konu başlığında kullanılmıştır (Alexander, 2013) (Şekil 5).

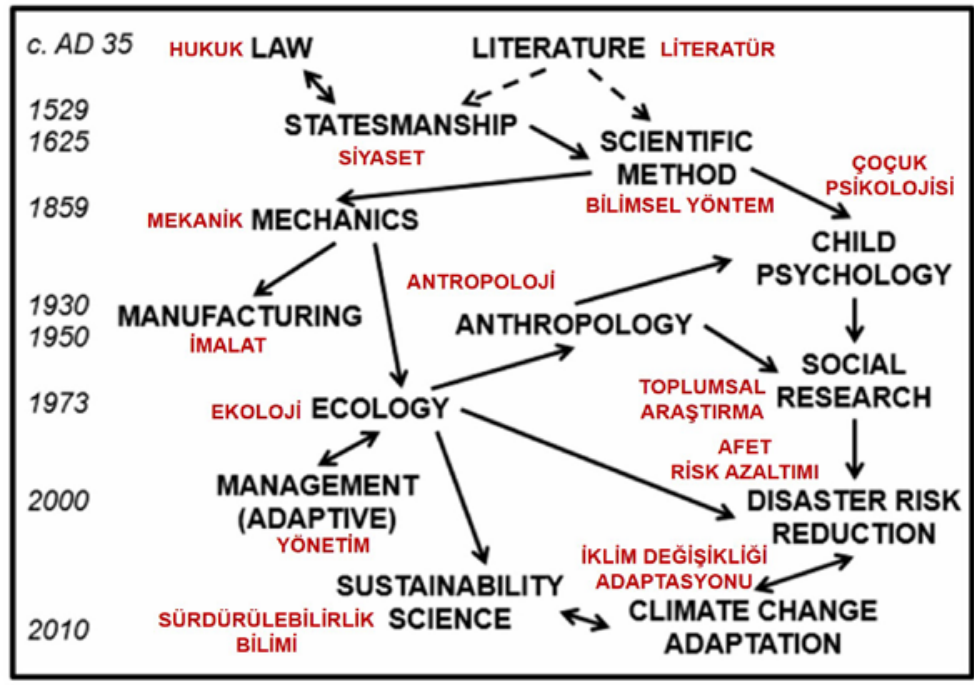

Şekil 5. Dayanıklılık (Resilience) kavramının kullanım alanları gelişiminin şematik diyagramı (Alexander, 2013)

Farklı disiplin ve konu başlıklarında kullanım; "Resilience" kavramına türkçe karşılığı olarak "Dayanıkıı̆̆ın" dışında dirençlilik, esneklik, rezilyans, sağlamlık, yılmazlık, elastikiyet kullanımlarını da getirmiştir. Okay ve arkadaşları (2018) "resilience" karşılığı olarak direnç kelimesini kullanmış ve afete dirençli (disaster resilience) toplumlar için afet risk yönetiminin yaygınlaştırılması gerekliliğine vurgu yapmıştır. Gerçek ve arkadaşları (2019) çalışmalarında; "resilience" kavramını rezilyans olarak ele alarak organizasyonel rezilyans (organizational resilience) kapasitesini, örgütlerin kriz anlarında ve yıkıcı olaylar karşısında sağ kalma ve dönüşebilme becerileri olarak tanımlamıştır.

Bu kavram etimolojik olarak incelendiğinde dayanıklılık (resilience) kelimesinin latince "resalire" kelimesinden türediği görülmektedir (URL 15). Burada "re-", yeniden ya da geri; "salire" ise sıçramak ya da atlamak anlamındadır. Geri sıçramak ve geri atlamak bu noktada etki karşısında mevcut durumunu korumak veya etki sonrasında mevcut durumuna geri dönebilmek olarak kullanılmaktadır.

Folke ve arkadaşlarına (2010) göre Resilience (dayanıklılık) ilk olarak Holling (1973) tarafından kaygı verecek, problem çıkartacak durumlar karşısında ekosistemin orijinal halini koruma kapasitesi olarak tanımlanmış ve ekoloji alanında bilimsel makalelerde yer almaya başlamıştır.1960'ı yıllarda ve 1970'li yılların başında; dayanıklılık düşünce (resilience thinking) yaklaşımı giderek önem kazanmaya başlamıştır (UN-Habitat 1). Davoudi ve arkadaşları (2012) tarafından Resilience (dayanıklıık); Mühendislik Dayanıklıık 
(Engineering Resilience), Ekolojik Dayanıklılık (Ecological Resilience), Evrimsel Dayanıklılık (Evolutionary Resilience) başlıkları çerçevesinde anlatılmaktadır. Mühendislik Dayanıklıık; etki karşısında sistemin ne kadar hızlı toparlandığı ve denge haline gelebildiği ile ölçülmektedir (Holling, 1973). Ekolojik Dayanıklıık (Ecological Resilience) ise sistemin mevcut yapısını değiştirmeden sisteme etki eden rahatsızlık verici olay ve etkisinin sistem tarafından absorbe edilmesi olarak tanımlanmaktadır (Holling, 1996). Evrimsel Dayanıklılık (Evolutionary Resilience) bilimsel kaynaklarda zaman zaman Sosyo-Ekolojik Dayanıklılık (Socio-Ecological Resilience) olarak ta kullanılmaktadır (Folke ve diğ. 2010; Davoudi, 2012). Evrimsel Dayanıklılık; stresler ve gerginlikler karşısında mevcut normale dönmenin yanında, kompleks yapıdaki sosyo-ekolojik sistemin değişme, adapte olma ve dönüşebilme yeteneği olarak tanımlanmaktadır (Carpenter ve diğ. 2005).

Hem "dayanıklılık" kavramı hem de "dayanıklılık düşünce yaklaşımı"; kentlerin depremden salgın hastalığa, siber saldırılardan su sıkıntısına, göçten şiddetli yağışlara, sınırlı kaynaktan kapasite azlığına vb. çok çeşitli akut şok ve kronik streslerin yıkıcı etkilerine, yerel ve küresel olarak sıklıkla maruz kalması ve hasar görme olasılıklarının giderek artmasından dolayı, sorunlar ile baş edebilmek adına literatürde kendine oldukça fazla yer bulmuştur.

Yaşanan tecrübeler; akut şok ve kronik streslerin etkilerinin idari sınırlardan bağımsız olduğunu, sadece yerel değil küresel anlamda da olumsuz sonuçlar doğurduğu göstermektedir. Bu durum sorunlar karşısında dayanıklı kentler yaratmak adına yerel çözümler ile birlikte alınması gereken küresel önlemlerin ve birlikte çözüm önerileri üretmenin önemini ortaya koymuştur.

Dünya devletleri kentlerin karşı karşıya kaldığı bu sorunlarla baş edebilmek, ilgili risklerini azaltmak ve küresel çözümler ortaya koyabilmek için; 1970'li yılların sonundan günümüze, farklı sorun başlıklarında paneller düzenlemiş, çerçeveler, sözleşmeler, stratejiler, eylem planları ve gündemler oluşturmuş, anlaşmalar yapmış ve küresel hedefler belirlemiştir (Şekil $6)$.

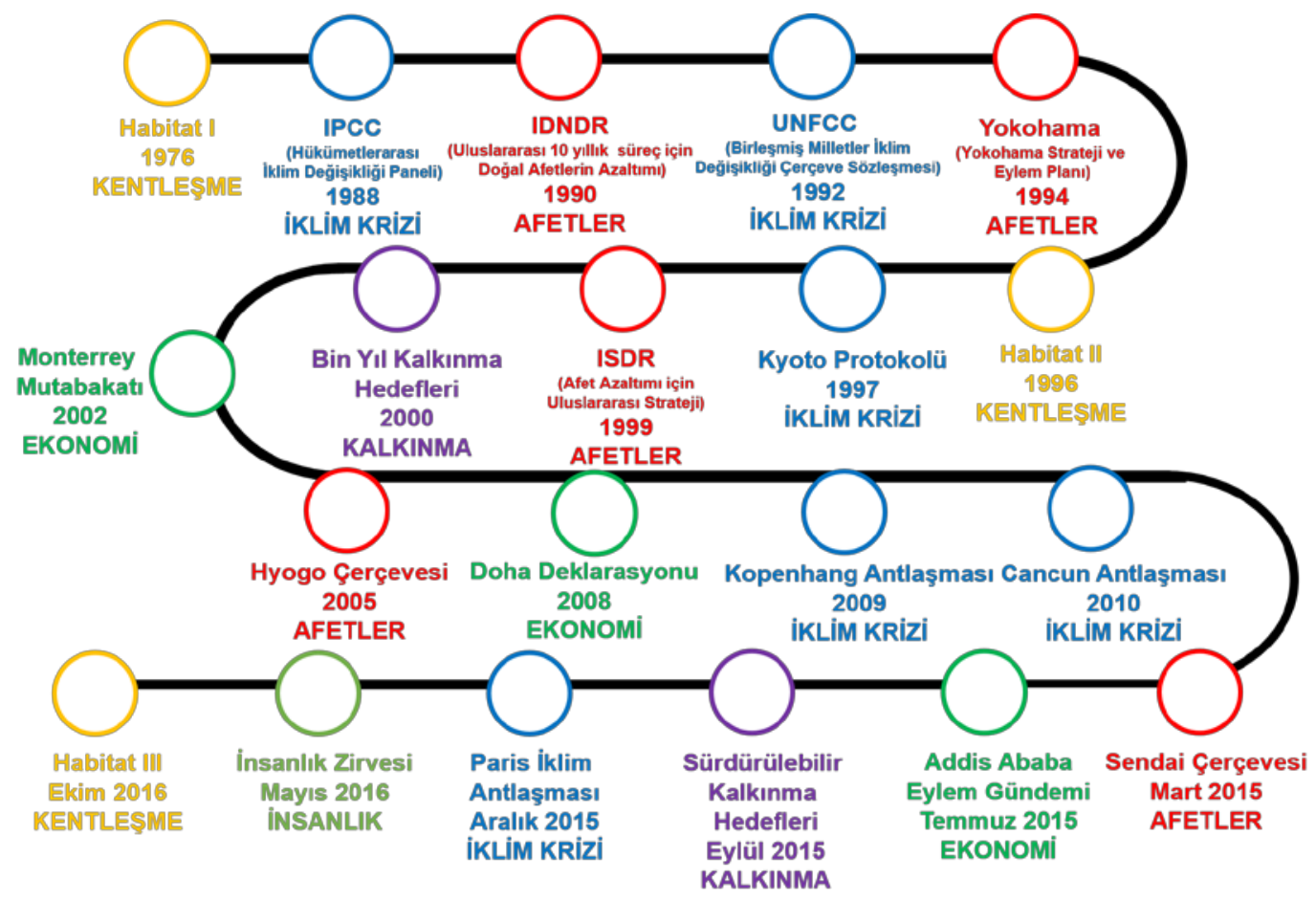

Şekil 6. Kentsel dayanıklıık adına önemli küresel ajandaların tarihsel süreci 
Dayanıklıık yaklaşımı bu süreçte özellikle, 2015 ve sonrası yayınlanan 6 önemli küresel ajandada öne çıkan tema olarak göze çarpmaktadır. Bu küresel ajandalar; "Afet (Sendai Çerçevesi), Ekonomi (Addis Ababa Eylem Gündemi), Kalkınma (Sürdürülebilir Kalkınma Amaçları), İklim Krizi (Paris Antlaşması), İnsanlık (Dünya İnsanlık Zirvesi) ve Kentleşme (Habitat III)" konu başlıklarında kentlere yerel ve veya küresel olarak çözüm önerilerinde bulunup, stratejiler sunarak dayanıklılık yaklaşımı (resilience approach) için önemli bir temel oluşturmuşladır (Şekil 7).

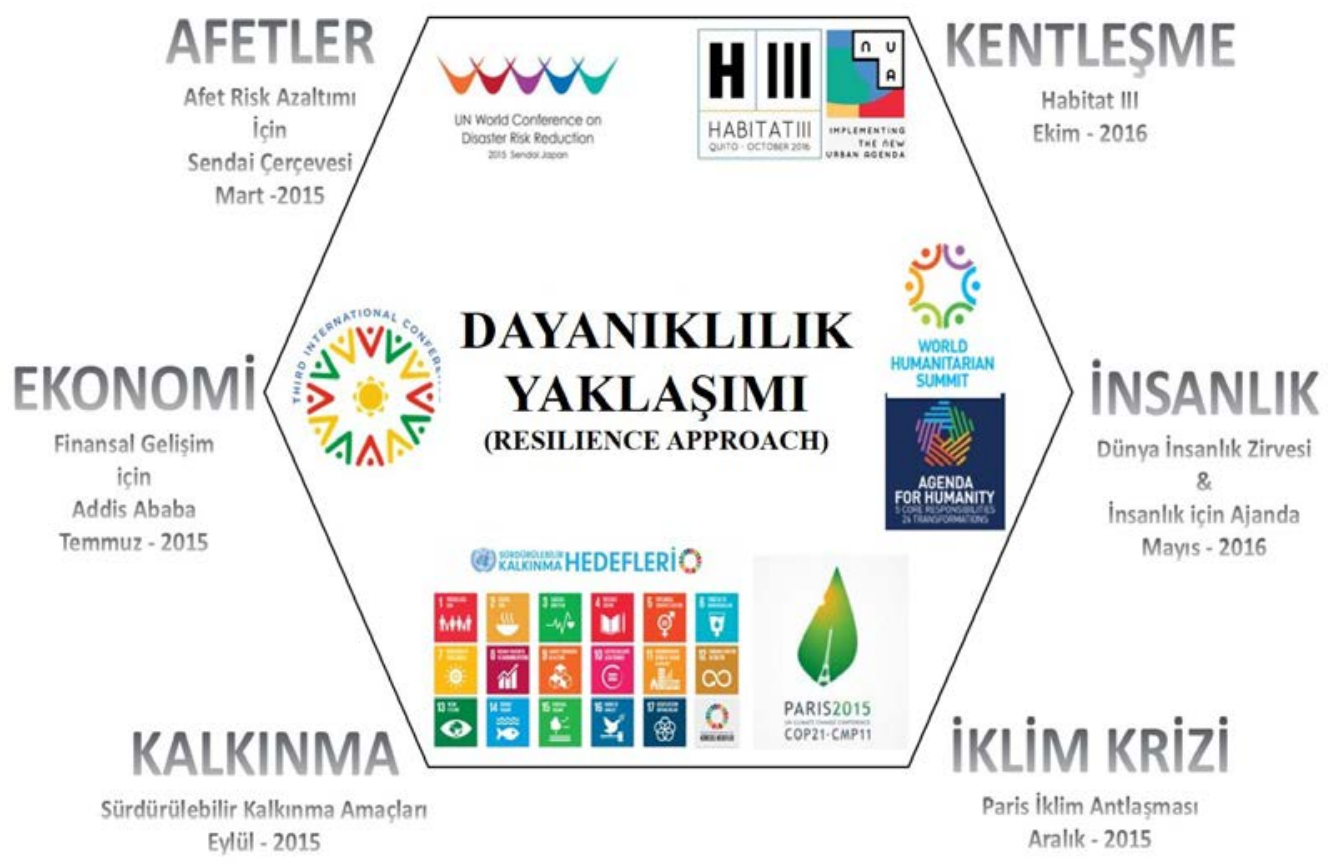

Şekil 7. Küresel ajandalarda dayanıklılık (resilience) kavramının yeri

Afet riski azaltımı için Sendai Çerçevesi; 1989 IDNDR (International Decade for Natural Disaster Reduction), 1994 Yokohoma (Yokohoma Strategy and Plans of Action), 1999 ISDR (International Strategy for Disaster Reduction) ve 2005 Hyogo (Hyogo Framework for Action 2005 -2015) üzerine kurgulanmıştır (Şekil 6). Sendai; daha dayanıklı ve sorunlarla baş edebilir yaşam ve yaşam alanları için ilgili tüm başlıklarda afet risklerinin azaltılmasını amaçlamıştır. Sendai Çerçevesinin 4 önceliği; afet risklerinin anlaşılması, afet risk yönetişiminin kuvvetlendirilmesi, dayanıklılık (resilience) için afet riski azaltımı çalışmalarına yatırım yapılması ve afet sonrasında efektif müdahale ile iyileşme, rehabilitasyon ve yeniden yapılanma dönemlerinden afet öncesi normal yaşantıya daha iyi şartlarda ve çabuk dönebilmek adına afet hazırlıklarının arttırılmasıdır (UN3). Bu öncelikleri ile Sendai; afet risk azaltma odaklı hedef ve öncelikleri doğrultusunda, afet karşısında dayanıklıı̆ğın oluşturulmasını destekleyen etkili bir çerçevedir.

Hemen arkasından Temmuz 2015 te gelen; 2002 Monterrey Mutabakatı (Monterrey Consensus) ve 2008 Doha Deklarasyonu (Doha Decleration) çıktıları üzerine inşa edilen Addis Ababa Eylem Gündemi (Addis Ababa Action Agenda) finansal gelişim ile finansman kaynaklarının ve kalkınmanın canlandııımasını hedeflemiştir (Şekil 6). Küresel kalkınma hedeflerinin temel basamaklarından biri olan bu gündem; yurtiçi kaynakların efektif kullanımı ve mobilizasyonu, yurtiçi ve yurtdışı özel işletme ve finans yatırımları, kalkınma için işbirliği, sürdürülebilir gelişim için finansal hedefler arasındaki sinerjinin yakalanması konu başlıklarının altını çizmiştir (UN4). Addis Ababa yerel ve küresel sunduğu finansal işbirlikleri önerileri ve çözümleri ile ekonomik dayanıklılığı destekleyen bir gündem olarak yerel ve küresel platformlarda yer almıştır 
"Sürdürülebilir Kalkınma Amaçları" 2000 yılında yayınlanan, Bin Yıl Kalkınma Hedefleri üzerine geliştirilmiştir (Şekil 6). Sürdürülebilir Kalkınma kapsamında 17 adet ana amaç bulunmaktadır (URL16) (Tablo 1). Bu başlıklar etrafında oluşturulan hedeflerin; kalkınma önünde engel oluşturan sorunların çözümü için stratejiler sunmak ile beraber dayanıklılık yaklaşımı için güçlü bilgiler ve öneriler verdiği de görülmektedir. Sürdürülebilir Kalkınma Amaçları; tüm canlıların ve yaşam alanlarının korunarak ve gelişerek sürdürülebilirliğine hizmet eden önemli bir ajandadır.

Tablo 1. Sürdürülebilir Kalkınma Amaçları (URL16)

\begin{tabular}{|c|c|}
\hline & Amaçlar \\
\hline 1 & Yoksulluğa son \\
\hline 2 & Açlığa son \\
\hline 3 & Sağlık ve kaliteli yaşam \\
\hline 4 & Nitelikli eğitim \\
\hline 5 & Teplumsal cinsiyet eşitliği \\
\hline 6 & Erişebilir ve temiz enerji \\
\hline 7 & Sanayi, yenilikçilik ve altyapı \\
\hline 8 & Eşitsizlikleri azaltıması \\
\hline 9 & Sürdürülebilir şehirler ve altyapı \\
\hline 10 & Sorumlu üretim ve tüketim \\
\hline 11 & İklim eylem \\
\hline 12 & Sudaki yaşam \\
\hline 13 & Karada yaşam \\
\hline 14 & Barış, adalet, güçlü kurumlar \\
\hline 15 & Amaçlar için ortaklıklar \\
\hline 16 &
\end{tabular}

Sürdürülebilir Kalkınma Amaçlarının (Sustainable Development Goals) en önemli hedeflerinden biri 13. hedef olan iklim eylemidir. Birleşmiş Milletlerin verilerine göre 20002019 yılları arasında gerçekleşen 7348 adet afetin yaklaşık \%83'ü iklimsel afetlerdir (CRED, UNDRR). İklim Değişikliği Panelinin oluşturulması, Birleşmiş Milletler İklim Değişikliği Çerçeve Sözleşmesi, Kyoto Protokolü, Kopenhag ve Cancun Antlaşmaları üzerine kurgulanan; 195 ülke tarafından 2015 Aralık ayında Paris'te imzalanan ve 2016 yılında sadece 186 ülke tarafından New York'ta onaylanan Paris İklim Antlaşması; iklim değişikliği ya da krizine küresel anlamda çözüm bulunması adına çok önemlidir (Şekil 6). Paris iklim antlaşmasının; adaptasyon (iklim değişikliği etkilerinin üstesinden gelmek adına), kayıp ve hasar (iklim değişikliği ile bağlantılı kayıp ve hasarları minimize etmek için) ve kentlerin rolü (dayanıklılığın oluşturulması) ilkeleri, kentlerin iklim olayları karşısında dayanıklılığına hizmet etmek adına oluşturulmuştur (PARiS). Özellikle antlaşmanın 7. Maddesi; iklim değişikliğine karşı dayanıklılığın (resilience) arttırıması üzerine durmuştur (PARIS). İklim değişikliği olumsuz etkilerinin yerel çözümlerin yanında alınacak küresel önlemlerle azaltılması; iklimsel sorunlar karşısında dayanıklıı̆̆ının oluşturulmasında çok mühim bir adımdır.

Bir diğer önemli küresel ajanda Mayıs 2016 yılında gerçekleştirilen İnsanlık Zirvesidir (World Humanitarian Summit) (Şekil 6). İnsanlık zirvesi; insani ilkelerin yeniden teyit edilmesini, ülke ve toplumların sorunlara ve krizlere karşı hazırlıklı olarak doğru müdahale etmesini, dayanıklıı̆ın (resilience) arttırııması için gerekli aksiyonların alınmasını ve taahhütlerin başlatılmasını ve dünya genelinde hayat kurtarmak adına yapılmış iyi örneklerin paylaşılmasını hedef belirlemiştir (WHS). İnsani değerleri göz önünde tutan kalkınma çözümleri üretmenin, mevcut ulusal ve yerel sistemi geliştirip güçlendirmenin, krizleri önceden öngörmenin ve var olan kapasiteyi arttırmak adına yatııım yapmanın altını çizen bu ajanda; dayanıklıık yaklaşımı ve dayanıklıığın oluşturulması adına önemli bir zirvedir. 
1976 yılında ilki, 1996 yılında ikinci ve 2016 Ekim ayında 3. gerçekleşen Habitat III olarak bilinen bir diğer önemli küresel ajanda; sürdürülebilir kalkınma ve iklim değişikliğini kentsellik bakış açısında değerlendirmiştir (Şekil 6). Habitat III kapsamında; üye ülkeler tarafından fikir birliğine varılan "Yeni Kent Ajandasında (New Urban Agenda)"; kentsel sistemlerde dayanıklılık paradigması planlanması, kentsel gelişimin yönetilmesine imkân sağlayacak yasal ve yönetsel çerçevelerin oluşturulması, kentsel alanların risk analizlerinin yapılması ve dayanıklı kentler için yerel ekonomilerde iyi uygulamaların teşvik edilmesi ve güvenli pazarlama için stratejilerinin oluşturulması belirgin bir şekilde öne çıkmıştır (UN5). Yeni kent ajandası; kentlerin dayanıklııı sürecini destekleyen önemli bir ajandadır.

Dayanıklıık yaklaşımının yaygınlaştırılması ve içselleştirilmesi için temel oluşturan bu 6 önemli küresel ajanda güvenli, yaşanabilir ve sürdürülebilir yaşam ve yaşam alanları yaratmak adına değerli stratejilerini afet, ekonomi, kalkınma, iklim krizi, insanlık ve kentleşme konularında ayrı ayrı ortaya konmuştur. Ancak kentlerin; mevcut ve olası sorunlar karşısında baş edebilme gücünü arttırmak için sorunlarını, sorunların birbirlerini etkileme ve tetikleme durumlarını, kente etkilerini ve çözüm yollarını; ayrı ayrı değil, neden ve sonuç ilişkisi içerisinde holistik bir bakış açısı ve disiplinler üstü bir çalışma ile bütüncül bir şekilde değerlendirmeye intiyacı vardır. Kentlerin sorunlar ile baş edebilme gücü; kentin kentsel dayanıklılığını ortaya koymaktadır.

100 RC'ye (100 Resilient Cities) göre kentsel dayanıklılık (urban resilience); bireylerin, toplumun, kurumların, işletmelerin ve sistemlerin; hangi akut şok ve kronik stresi tecrübe ettiğine bakmaksızın hayatta kalma, adapte olma ve büyüme kapasitesidir (100RC, 2019). Birleşmiş Milletler İnsan Yerleşimleri Programı (UN-Habitat) ise kentsel dayanıklıı̆̆ı; kentsel sistemlerin ve kent sakinlerinin sürdürülebilirliği adına tüm şoklar ve stresler karşısında sürekliliğini korumak için adapte olma ve dönüşebilme yeteneği olarak tanımlamaktadır (UNHabitat 2). 100 RC tarafından hayatta kalma, adapte olma ve büyüme kapasitesi, UNHabitat'a göre sürdürülebilirlik için uyum sağlama ve dönüşebilme yeteneği olarak tanımlanan kentsel dayanıklılık; kent bütünün sorunlar karşısında kazanması veya geliştirmesi gereken özellikleri, yetenekleri ve becerileri ile oluşturulur ve arttırılır. Kentsel dayanıklıık için gerekli özellikleri, yetenekleri ve becerileri 100 RC (ARUP, TRF), UN-Habitat (UN-Habitat 3) ve Dünya Bankası (DB) tarafından tablo 2'deki gibi tanımlamıştır. Bu özellik, yetenek ve beceriler kentin sahip olması gereken kentsel dayanıklılık kabiliyetleridir.

Tablo 2. Kentsel dayanıklılık kabiliyetleri (özellikleri, yetenekleri, becerileri) (100 RC, UN-Habitat, Dünya Bankası)

\begin{tabular}{|c|c|c|c|c|}
\hline & & $100 \mathrm{RC}$ & $\begin{array}{l}\text { UN- } \\
\text { Habitat }\end{array}$ & $\begin{array}{c}\text { Dünya } \\
\text { Bankası }\end{array}$ \\
\hline 1 & Geçmiş tecrübelerden öğrenme - (Reflective) & $\mathrm{X}$ & $\mathrm{X}$ & $\mathrm{X}$ \\
\hline 2 & $\begin{array}{l}\text { Kaynakların doğru kullanımı, yenilenebilir alternatif } \\
\text { kaynakların yaratılması- (Resourceful) }\end{array}$ & $\mathrm{X}$ & & \\
\hline 3 & $\begin{array}{l}\text { Yönetilebilir, iyi tasarlanmış, dayanıklı sistemler - (Robust - } \\
\text { Robustness) }\end{array}$ & $\mathrm{X}$ & & $x$ \\
\hline 4 & Yedek kapasite varlığı - (Redundant) & $\mathrm{X}$ & & $\mathrm{X}$ \\
\hline 5 & $\begin{array}{l}\text { Değişen koşullar karşısında değişme, gelişme ve adapte olma } \\
\text { - (Flexible) }\end{array}$ & $x$ & & \\
\hline 6 & $\begin{array}{l}\text { Karar alma süreçlerinde geniş istişareye önem verme - } \\
\text { (Inclusive) }\end{array}$ & $\mathrm{X}$ & $X$ & $\mathrm{X}$ \\
\hline 7 & Birlikte çalışabilme becerisi- (Integrated) & $\mathrm{X}$ & $\mathrm{X}$ & \\
\hline 8 & $\begin{array}{l}\text { Kent bütününün sorunlar karşısında sürekliliğinin sağlanması } \\
\text { - (Persistent) }\end{array}$ & & $X$ & \\
\hline 9 & $\begin{array}{l}\text { Değişen durumlar karşısında uyum sağlama ve gelişme } \\
\text { (Adaptable) }\end{array}$ & & $x$ & \\
\hline 10 & Devam edebilmek için dönüşebilme (Transformative) & & $\mathrm{X}$ & \\
\hline 11 & $\begin{array}{l}\text { Sistemler arasındaki koordinasyon, bilgi paylaşımı ve işbirliği } \\
\text { (Coordinated) }\end{array}$ & & & $x$ \\
\hline
\end{tabular}


Her kentin tarihsel ve gelişim süreçlerini, vizyonlarını, mevcut ve olası sorunlarını temel alarak; kentsel dayanıklılık kabiliyetlerini (özellikleri, yetenekleri ve becerileri) kente özgü olmak koşulu ile ortaya koyması ve geliştirmesi gerekmektedir.

Tarihsel arşivler incelendiğinde kentlerin belli zaman aralıklarında belli sorunlar ile karşı karşıya kaldığını görmek mümkündür. Geçmişten günümüze yaşanmış sorunlar, afetler, acil durum, krizler vb. günlük hayatı sekteye uğratan olaylar ile ilgili tecrübelerin hatırlanması, değerlendirilmesi ve neden sorun oluşturduğunun ortaya konması; yaşanması muhtemel kentsel problemler hakkında ipucu verirken, yapılması ve yapılmaması gerekenler hakkında belirleyici olabilir. Bundan dolayı kentler; gelecek stratejilerini oluştururken ve yatırım programlarını önceliklendirirken mutlaka geçmiş tecrübelerini göz önünde bulundurmak zorundadır.

Kent süreçleri ile ilgili doğru karar verebilmek ve hızlı ilerleyebilmek için; geniş istişareye önem verme ve koordineli çalışma; mevcut, olası ve öngörülemeyen sorunların çözümü için tüm kent paydaşlarının birlikte olabilmesi; sorumlulukların doğru dağıtılığı bir organizasyon şemasının oluşturulması ve kent paydaşlarının tüm kent sorunları ile ilgili farkındalığının arttırıması için önemli bir fırsat sunar.

Doğru tasarlanmış, sağlam, yönetilebilir ve devamlılığı olan sistemlerin oluşturulması ve bu sistemler arasında koordinasyonun sağlanması; kenti tehdit eden akut şok ve kronik stresler karşısında sistemlerin işlevselliğinin devamlılığı, mücadele kapasitesinin arttırılması ve normal şartlara hemen ve gelişerek dönebilmek için çok önemlidir.

Kentlerimizin; sınırlı ve giderek azalan kaynaklarını doğru yönetmesi ve yeni kaynaklar oluşturması, değişen durumlar için alternatif stratejiler üretebilmesi; sürdürülebilir gelişimin temellerinden biridir.

Kentsel sistemlerin devamlılığı için yedek kapasitenin varlığı; problemler, aksaklıklar karşısında sistemlerin fonksiyonelliğinin güvencesi olup hizmet garantisi için gereklidir.

Kentler; gelecekte de varlık gösterebilmek için sorunlar ile karşılaştıklarında veya sonraki süreçlerde olumsuz etkilerini absorbe etme, sebep olduğu değişimlere adapte olma, gerektirdiğinde ise dönüşebilme ve değişebilme ve sorunlar karşısında sürekliliğini sağlama gücünü geliştirmek zorundadır.

Kentin; kentsel dayanıklılık kabiliyetlerine sahip olması ile sağlanabilecek bu üstünlükler kentsel dayanıklılığın temelini oluşturmaktadır.

"Kentsel Dayanıklılık" (urban resilience); kent bileşenlerinin, sektörlerin, sistemlerin ve kent paydaşlarının, mevcut ve olası akut şok \& kronik stresler ile baş edebilme gücü olup, sürdürülebilir gelişimi için kentlerin oluşturduğu savunma mekanizmasıdır.

Kent için zaman içinde inşa edilen ve süreç içinde arttırılması hedeflenen kentsel dayanıklılık; daha güçlü, güvenilir, yaşanabilir ve sürdürülebilir kent bütünü için hem niteliksel hem de niceliksel gelişmeyi gerektiren sistematik ve dinamik bir süreçtir.

UN-Habitat yaklaşıma göre kentler; kentsel altyapı, yapılı çevre, çevre, iletişim ağı, sosyal, kültürel, politik ve ekonomik yapı gibi farklı ağları ve elementleri içeren kompleks bir sistemdir. Bu kompleks sistem içerisinde kentsel sistemler ise kentsel alan içerisinde bu ağ ve elementlerin birbiri ile bağlantıları, etkileşimleri, operasyonları ve organizasyonları ile ilgili süreçleri yönetmektedir (UN-Habitat 4). 
Farklı ağ ve elementleri içeren kompleks yapısı ile kent bütününün akut şok ve kronik stresler karşısında baş edebilme gücünün ve kapasitesinin artırılması; kentsel dayanıklılık kabiliyetlerinin kent bütününe yani kent paydaşlarına, kent bileşenlerine, kentsel sistemlere ve sektörlere kazandırılması ile sağlanabilir.

\section{KENTSEL SORUNLAR KARŞISINDA KENTSEL DAYANIKLILIK NASIL SAĞLANIR?}

Kentsel dayanıklılık (urban resilience) bir diğer tanımı ile kentin sorunlar karşısında geçmişinden ders alıp, mevcut durumunu iyi anlayıp, geleceğini de öngörüp, kent bütününde oluşturduğu bir savunma mekanizması yani sorunlar karşısında kentin bağışıklığıdır (Şekil 8). Kentin sürdürülebilir gelişimi adına; akut şok ve kronik stresler karşısında kent için savunma kalkanı olan kentsel dayanıklıığın oluşturulması; kentsel dayanıklılık kabiliyetlerinin kent bütününe (kent bileşenleri, paydaşları, kentsel sektörler ve sistemler) kazandırılması ile mümkün kılınabilir (Tablo 3).

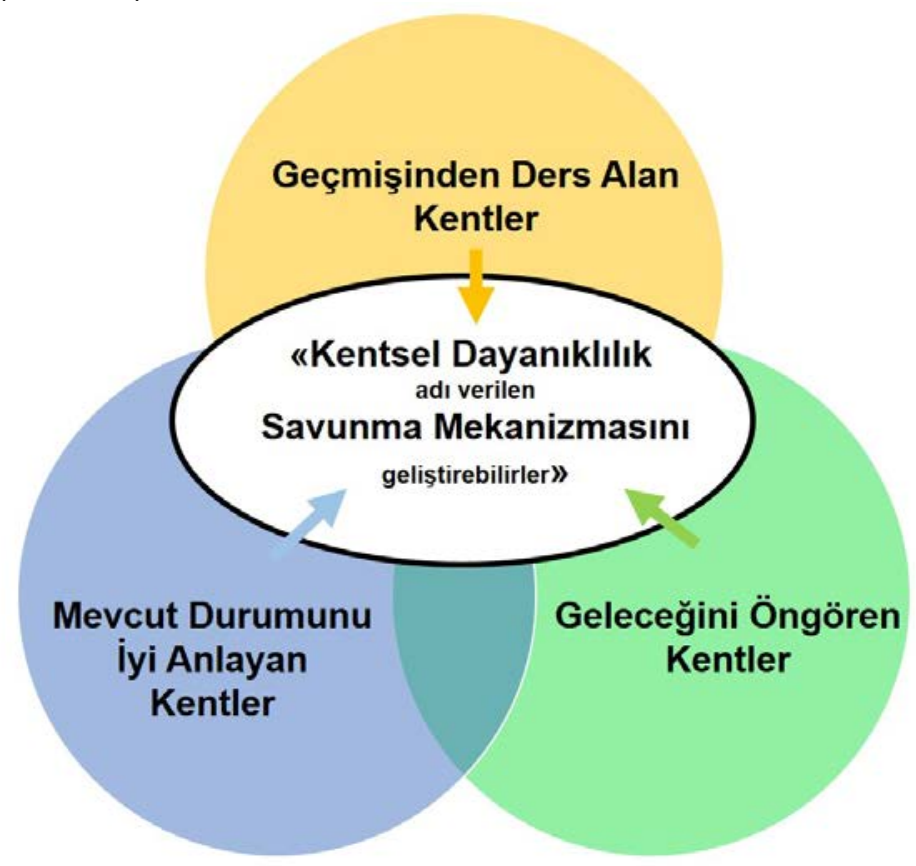

Şekil 8. Kentin savunma mekanizması kentsel dayanıklılık

Kent bileşenlerinin yani üst ve altyapısının, çevresinin, iletişim ağının, kültürel mirasının, siber ortamının, sosyal, kültürel, ekonomik ve yönetim yapısının, akut şok ve kronik stresler karşısında güçlü tutulması, baş edebilme gücünün arttırılması, adaptif kapasitesinin ve absorbe etme yeteneğinini geliştirilmesi; kentlerin kentsel dayanıklılığı ile mevcut yapısının korunmasının yanında gelişerek geleceğe aktarılması noktasında sürdürülebilirliği için çok önemlidir. Örneğin yapılı çevrenin ve altyapının deprem tehlikesi karşısında afet dayanıkı hale getirilmesi, siber saldırılar karşısında siber ortamın güvenliğinin sağlanması, çevrenin sürdürülebilirliği karşısında en büyük tehditlerden biri olan çevre degradasyonuna neden olan aktivitelerin önlenmesi ya da azaltılması, yoksulluk için çözümler üretilerek sosyal yapının daha da sağlamlaştırıması, ekonomik çeşitlilik ve istihdamın artırılmasına yönelik uygulamalar ile ekonomik yapının güçlendirilmesi ile işsizlik vb. sorunların giderilmesi ve kültürel mirasa sahip çıkılması; kentin geleceği ve dolayısı ile kent bileşenlerinin sürdürülebilirliği için şimdiden atılması gereken önemli adımlardır (Tablo 3).

Kentsel sektörlerin (sosyal koruma, eğitim, enerji, sağlık, bilgi iletişim teknolojileri, yerel ekonomi, lojistik \& tedarik zinciri, finans, katı atık, ulaşım ve erişebilirlik, su ve sanitasyon, gıda sistemi) akut şok ve kronik streslerden etkilenme dereceleri de kentsel dayanıklılık için 
önemli bir kriterdir. Bundan dolayı sektörlerin işlevselliği ile ilgili risklerin azaltılması, mücadele kapasitesinin arttırılması, oluşturulacak yedek kapasite ve alternatif strateji önerileri ile sektörlerin her durumda fonksiyonelliğinin sağlanması şoklar ve stresler karşısında kentsel sektörlerin devamlılığı için gereklidir. Örneğin gıda güvencesizliği ve bağımlılı̆ı karşısında gıda sisteminin lokal çözümler ile geliştirilmesi, nüfus artışına ve tüketim trendlerine paralel artan su kullanımı ile ilgili tedbirlerin alınması ve tüketim alışkanlıklarının değiştirilmesi, kuraklık tehlikesi karşısında mevcutta oluşmaya başlayan su sıkıntısının giderilmesi, enerji bağımlıı̆ı ve tedariği ile ilgili problemlerin ortadan kaldırılması için yenilenebililr enerji kaynaklarından elde edilen enerji miktarının arttırıması, eğitim ve sağlık hizmetlerindeki eşitsizlik ve erişebilirlik sorununa çözüm üretilmesi, bilgi ve iletişim teknolojilerinde güvenlik problemlerinin halledilmesi, zorunlu nedenler ile göç edenlere sosyal koruma kapsamında stratejilerin üretilmiş olması olası ve mevcut şok ve stresler karşısında kentsel sektörlerin hizmet vermeye devam etmesi için gereklidir (Tablo 3).

Kentsel sistemlerinde yani kent başlığı altında ilgili bağlantıların, etkileşimlerin, operasyonların ve organizasyonların da maruz kaldığı küresel pandemi, su baskını, deprem, ekonomik krizler vb. akut şok ve kronik stresler karşısında iş sürekliliğinin ve sürdürülebilirliğinin sağlanması; sistemin kentsel dayanıklılık yeteneği ile ilgilidir (Tablo 3).

Kentin her bir kent bileşeninin, kentsel sektörünün ve kentsel sisteminin; mevcut ve olası akut ve şok kronik stresler ile baş edebilme gücünün arttırılması süreci boyunca, geçmiş tecrübeleri göz önünde bulundurma, kaynakları doğru kullanma ve yenilebilir alternatif kaynaklar yaratma, kapasite arttırma ve yedek kapasite oluşturma, değişen koşullar karşısında değişme ve gelişme süreçlerine açık olma, absorbe etme, adapte olma, dönüşebilme yeteneğini kazanma, karar alma süreçlerinde geniş istişareye, birlikte çalışmaya, koordinasyon ve işbirliğine önem verme ve işlevselliğin sürekliliğini sağlama vb. kabiliyetlerini kazanması kentsel dayanıklılık ve sonrasında sürdürülebilirlik için çok önemlidir (Tablo 3).

Tablo 3. Kentsel sorunlar karşısında dayanıklılık inşa edilmesi gereken kent bütünü

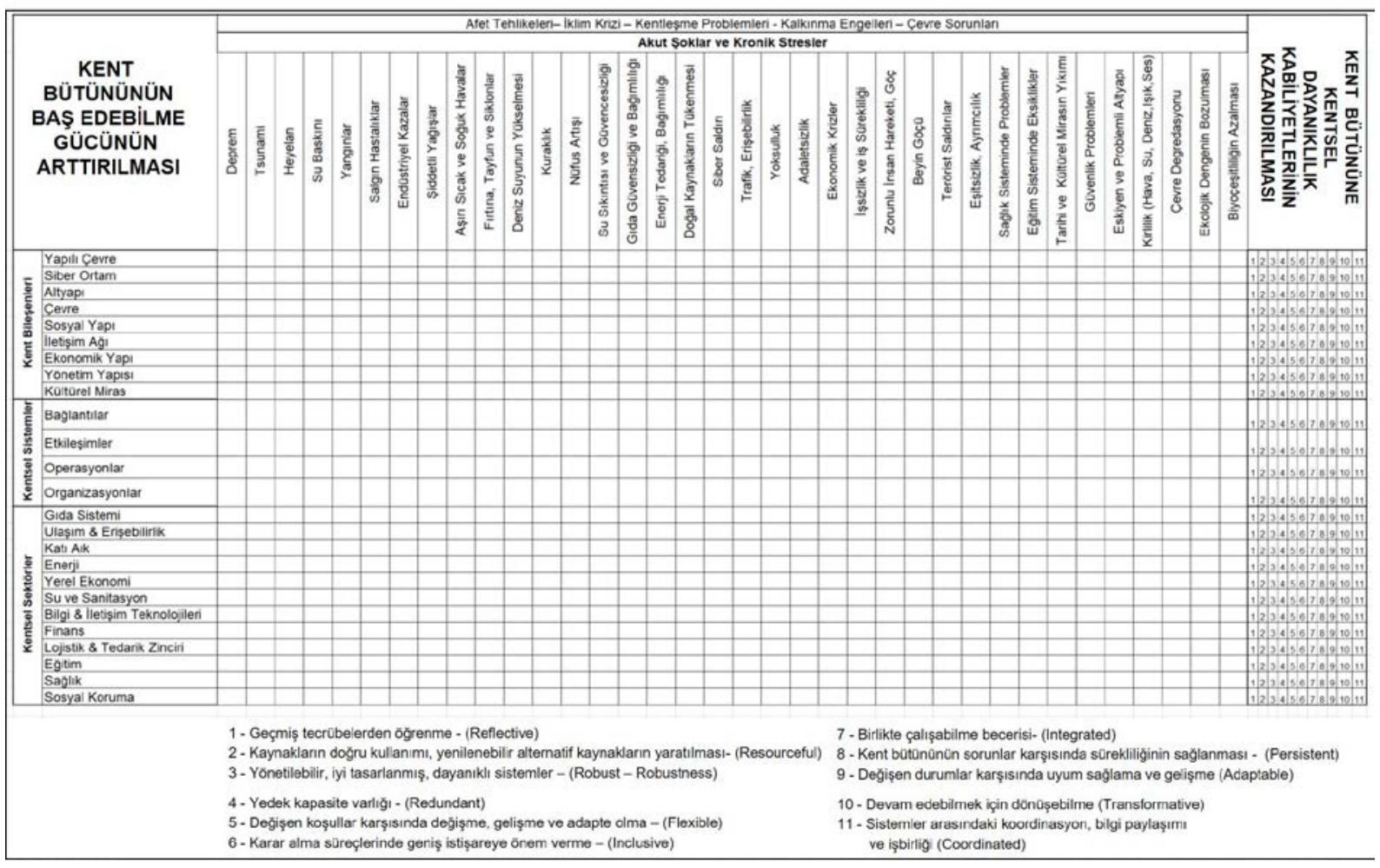


Kent bütününün; akut şok ve kronik stresler karşısında kentsel dayanıklıığını arttırıp sürdürülebilir kılmak için öncelikli olarak kentin soyut ve somut gerçekliklerinin değerlendirilmesi gerekmektedir. Kentsel dayanıklılığını oluşturmak, inşa etmek ve arttırmak adına değerlendirilmesi gereken gerçeklikleri aşağıdaki gibidir (Tablo 4).

Tablo 4. Kentsel dayanıklılık için oluşturulması ve veya geliştirilmesi gereken kent gerçeklikleri

\begin{tabular}{|c|c|}
\hline 1 & $\begin{array}{l}\text { Yerel ve küresel sorunlar karşısında; tehlike, risk, hasar görebilirlik analizlerinin varlığı ve kent } \\
\text { uygulamaların bu analizler temel alınarak yapılması }\end{array}$ \\
\hline 2 & Üst ve alt yapının sağlamlığı, uygunluğu, kapasitesi, erişilebilirliği \\
\hline 3 & Güvenli ve erişilebilir barınma yeterliliği \\
\hline 4 & Ulaşım ağının işlevselliği, sağlamlığı ve devamlılığı, yaygınlığı \\
\hline 5 & İçme, kullanma ve atık su ağının yaygınlığı, sağlamlılığı, kapsamı \\
\hline 6 & Katı atık ağının kapsamı, erişebilirliği, geri dönüşüm ve enerji kazanımı, imha etme operasyonları \\
\hline 7 & Kritik tesislerin uygun ve erişilebilir alanlarda varlığı, sağlamlığı, eşit hizmet verebilmesi \\
\hline 8 & Kritik tesis ve hizmetlerin sorunlar karşısında devamlılığı \\
\hline 9 & Eğitim tesislerinin, kapasitesi, yeterliliği, devamlılığı, işlevselliği ve ilgili sistemlerin dayanıklılı̆ı \\
\hline 10 & Sağlık tesislerinin, kapasitesi, yeterliliği, devamlılığı, işlevselliği ve ilgili sistemlerin dayanıklılığı \\
\hline 11 & Açık alan kapasitesinin yeterliliği \\
\hline 12 & $\begin{array}{l}\text { Çevrenin sürdürülebilir kılınması (doğal alanların ve biyo çeşitliliğin korunması, hava, su, deniz ışık ve } \\
\text { ses kirliliğine yol açan nedenlerinin değerlendirilmesi) }\end{array}$ \\
\hline 13 & Doğal kaynakların ve ekosistem servislerinin (tarımsal, orman, otlak, su vb.) korunması \\
\hline 14 & Gıda güvencesizliği, üretimi, erişimi, tüketimi, bağımlıı̆̆ı, tedariği, lojistiği \\
\hline 15 & Su kaynaklarının tedariki, elverişliliği, erişimi, tüketimi, kapasitesi, lojistiği, \\
\hline 16 & Su güvencesizliği ve alternatif su kaynaklarına erişim \\
\hline 17 & Enerji kaynaklarının çeşitliliği, tüketimi, tedariki, kapasitesi, kaynakların yenilenebilir olması, lojistiği \\
\hline 18 & Lojistik ve tedarik zincirinin devamlılığı ve alternatiflerinin varlığı \\
\hline 19 & Siber ortamların siber güvenliği \\
\hline 20 & Bilgi ve iletişim ağının yaygınlığı, kapsamı, devamlıı̆̆ı \\
\hline 21 & Teknolojik altyapının yaygınlığı, kapsamı, devamılıı̆ı \\
\hline 22 & $\begin{array}{l}\text { Temel (enerji, çevre, katı atık, ulaşım, su vb.), sosyal (sigorta, yeşil alan, kültürel aktiviteler, kültürel } \\
\text { miras vb.), insani (eğitim, sağlık, adalet, güvenlik vb.) servislerinin erişebilirliği, sürdürülebilirliği }\end{array}$ \\
\hline 23 & Sosyo-ekonomik ve kültürel stresler için stratejik ve eylem planlarının hazır olması \\
\hline 24 & $\begin{array}{l}\text { Sosyo-ekonomik ve kültürel streslerin azaltılmasına ve veya ortadan kaldırılmasına yönelik çalışmaların } \\
\text { belirlenmiş olması ve uygulamaya geçilmesi }\end{array}$ \\
\hline 25 & Sosyal kapsayıcılık, eşitlik, güvenlik ve adalet temelinde hizmetlerin sunulması \\
\hline 26 & Kırılgan grupların güçlendirilmesi \\
\hline 27 & Kültürel mirasın korunması \\
\hline 28 & Ekonomik istikrar, çeşitlilik, iş gücü devamlılığı, geçim kaynakları, piyasa etkinliği \\
\hline 29 & Güçlü, iyi planlanmış ve tasarlanmış yönetilebilir sistemlerin oluşturulması \\
\hline 30 & Yedek kapasite varlığı \\
\hline 31 & Sistemlerin işleyişinin devamlılığı \\
\hline 32 & Kurumsal kapasitenin baş edebilme gücü \\
\hline 33 & Kent bütününün; adaptasyon yeteneği ve absorbe etme becerisi \\
\hline 34 & $\begin{array}{l}\text { Kent bütününün; akut şok ve kronik stresler ile baş edebilmesini destekleyecek ilgili kanun, yönetmelik, } \\
\text { plan ve düzenleyici çerçevelerin yeterliliği ve uygulanabilirliği }\end{array}$ \\
\hline 35 & $\begin{array}{l}\text { Yetkilendirme ve organizasyon şemasının farklı sistem ve kurumları bir araya getirebilme gücü ve birlikte } \\
\text { çalışma becerisi }\end{array}$ \\
\hline 36 & Kent paydaşlarının akut şok ve kronik stresler hakkında farkındalığı ve aldığı̈ önlemler \\
\hline 37 & Kent paydaşlarının sürece katılımı \\
\hline 38 & Kent paydaşları arasında efektif, açık, anlaşılır iletişim ve koordinasyonun sağlanması \\
\hline 39 & Yerel yönetimin alternatif stratejiler geliştirme becerisi \\
\hline 40 & Yerel yönetimin finans kapasitesi \\
\hline 41 & $\begin{array}{l}\text { Kentin diğer ulusal ve uluslararası kentler ile sorunlar, dayanıklılık ve sürdürülebilirlik temalarında; bilgi, } \\
\text { tecrübe, uygulama ve iyi örnek paylaşımını destekleyecek platformların bir parçası olması }\end{array}$ \\
\hline
\end{tabular}

Kent gerçeklikleri; kentsel dayanıklılık için kentin intiyaçlarının ve kapasitesinin belirlenmesi ile geliştirilmesi gereken özelliklerinin ve kabiliyetlerinin ortaya konulmasında gereklidir. $\mathrm{Bu}$ gerçeklikler ışığında, kente özgü kentsel dayanıklılık yaklaşımının geliştirilmesi ise kent bütününün bu süreci daha kolay içselleştirilmesine yardımcı olacaktır. Ortaya konulacak yaklaşımın sorunlar ile baş edebilmenin yanında sürdürülebilir gelişim üzerine kurgulanması; 
hem kentlerin geleceğe taşınmasında hem de gelecek nesillerin ihtiyaçlarının karşılanması için çok önemlidir.

\section{SÜRDÜRÜLEBILIRIR DAYANIKLILIK YAKLAŞIMI}

Geçmişten günümüze; nüfusu ve nüfus yoğunluğu giderek artan, yerel ve küresel sorunlar ile mücadele eden kentler, çeşitli konu başlıklarında ve farklı ölçeklerdeki sorunlarını, kentsel dayanıklılık ve sürdürülebilirlik üzerine kurgulanmış bir yaklaşım ile çözebilir.

Kentsel Dayanıklılık; kentsel bileşenlerin, sektörlerin, sistemlerin ve kent paydaşlarının, mevcut ve olası akut şok \& kronik stresler ile baş edebilme gücü olup, sürdürülebilir gelişimi için kentlerin oluşturduğu savunma mekanizmasıdır. Bir kenti sürdürülebilir kılmak; risk yönetimi, kaynak tüketiminde gelecek nesillerin ihtiyaçlarının güvende ve göz önünde tutulması, kaynak sıkıntısına karşı alternatif kaynakların yaratılması, toplum refahının korunması, kapsayıcılık, güçlü bir ekonomi oluşturma ile innovasyonu destekleme ve arttırma ile sağlanır. "Sürdürülebilir Kentsel Dayanıklılık Yaklaşımı" tüm bu bilgiler ışığında kentler için sürdürülebilirlik, risk azaltma, doğaya saygı, insanı değerler ve doğru kalkınma tercihleri arasında; bütüncül bir değerlendirme, disiplinler üstü çalışma ve holistik bir bakış açısı ile şekillenmesi gereken bir yaklaşımdır.

"Sürdürülebilir Dayanıklılık Yaklaşımı" için "Doğaya ve İnsani Değerlere Saygı" öncelikli değer olarak; durumu ya da sorunu ele alış ve bakış biçimi olmalıdır.

Küresel ve Yerel sorunlar karşısında sorunları öngören ve ilgili riskleri azaltan "Afet Risk Azaltımı" stratejileri hedeflenmeli, hedef ile örtüşen uygun ve gerekli yatırım programları biran önce programlanmalı ve başlatılmalıdır. Kentin; risk azaltma çalışmalarının yanında sorunlarının neden olduğu olumsuz etkileri absorbe etme yeteneğini, yapısında oluşması muhtemel değişimlere adaptasyon kapasitesini ve gerekli durumlarda dönüşebilme kabiliyetini; bünyesinde oluşturması ve veya geliştirmesi çok önemlidir.

"Kentleşme" bakış açısı ise güvenli, yaşanabilir, doğaya saygılı, adil ve kapsayıcı vb. politikalar ve vizyonlar çevresinde şekillenmeli ve bu vizyonlar çerçevesinde alınacak doğru kararlar ile kentsel yaşam biçimlerinin gelişimleri ve kentleşme adımları tariflenmeli ve oluşturulmalıdır.

Kent bütününde ekonomik büyüme, sosyal gelişim ve çevresel yönetiminin yanında kent kaynaklarının mevcut yaşayanların yanında gelecekte de o kentlerde yaşayacak potansiyel insan sayısı da göz önüne alınarak değerlendirilmesi ile doğru kaynak yönetiminin yapılması, sistem ve hizmetlerin devamlılığı için yedek kapasite varlığının oluşturulması "Sürdürülebilir Gelişim" için gereklidir (Şekil 9).

Sürdürülebilir Dayanıklılık Yaklaşımı; öncelikli değer olarak Doğaya ve İnsani Değerlere Saygı, uygun yatırım ve gerekli uygulamalar ile yapılacak Afet Risk Azaltımı çalışmaları, doğru karar ile şekillenecek Kentleşme ve efektif stratejiler ile oluşturulacak Sürdürülebilir Gelişim ile çerçevesinde oluşturulmalıdır (Şekil 9). 


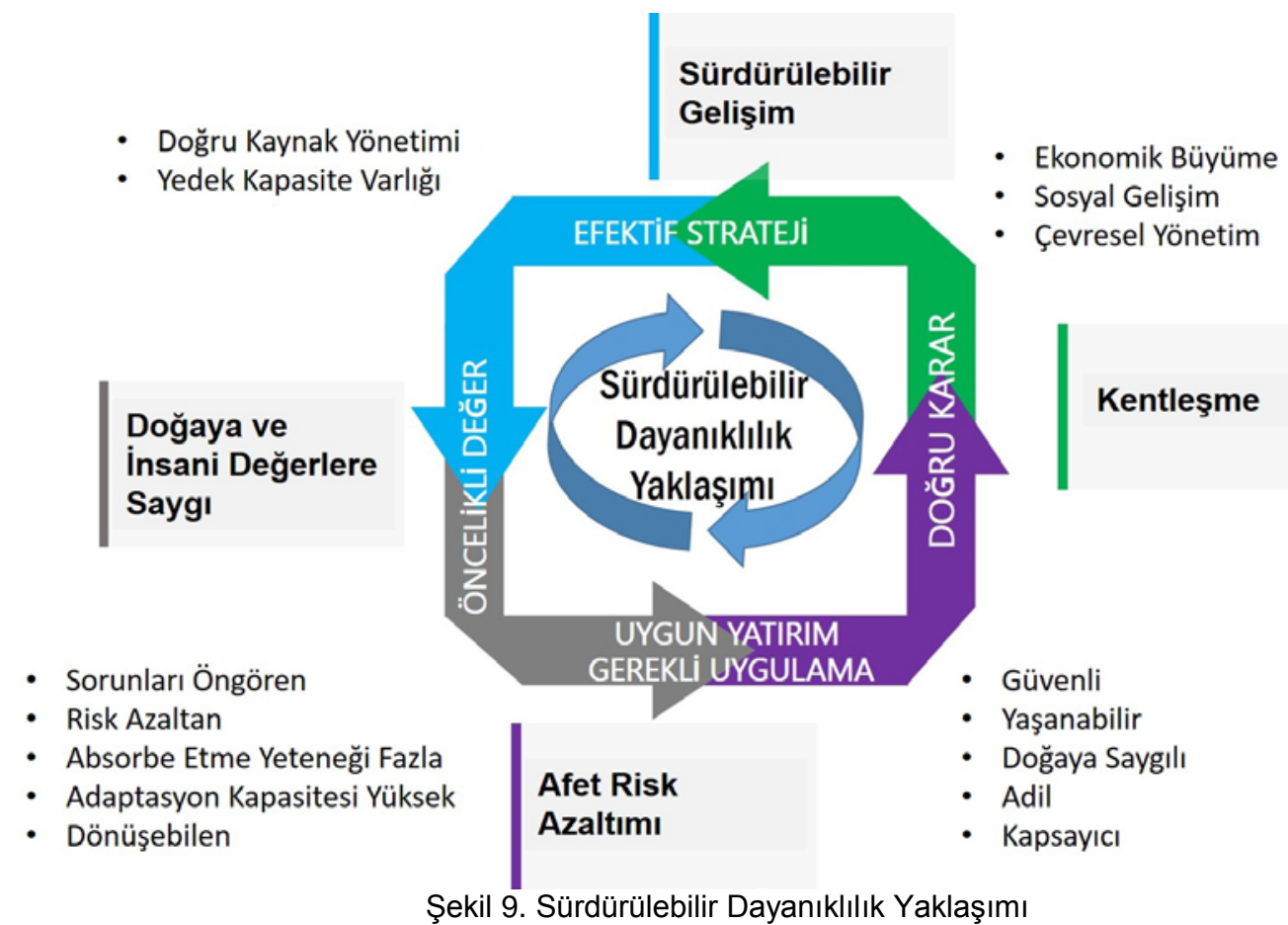

Sürdürülebilir Dayanıklılık Yaklaşımının kent bütününe entegre edilmesinin yolu; bu yaklaşım baz alınarak kente uygun kentsel dayanıklılık indeksinin oluşturulmasıdır. Bu indeks Tablo 4'de verilen kent gerçekliklerini mutlaka içermelidir. Kentin sürdürülebilir dayanıklıı̆ının ölçülmesi, izlenmesi, değerlendirilmesi ve gerekirse değiştirilerek güncellenmesi adına; bu indeks çerçevesinde kente özel ana eksen, hedef ve göstergelerin belirlenmesi gerekmektedir. Sürdürülebilir dayanıklılık yaklaşımı çerçevesinde oluşturulması beklenen bu indeks ile kentsel dayanıklıığın başarılı bir şekilde ölçülmesinin ve izlenmesinin tek yolu "Kentsel Dayanıklılık Ofis'inin (Urban Resilience Office)" kurulmasıdır.

Kentsel Dayanıklılık Ofisi; yerelde ve küreselde kent uzmanları, paydaşları, kentli ve karar vericileri için kent için birlikte hareket edebilecekleri bir platform olmalıdır.

Kentsel Dayanıklılık Ofis'inin sürdürülebilir dayanıklılık yaklaşımı ile farklı ölçek ve başlıklardaki çeşitli ve çoklu sorunların çözümü için disiplinler arası ve disiplinler üstü çalışmaya, bütüncül bir değerlendirmeye ve izlemeye fırsat verecek şekilde kurgulanması gerekmektedir.

Bu ofis kapsamında; kent üzerinde yetkili ve etkili paydaşların bir araya gelmesi; kent ile ilgili tüm konu başlıklarında eksik olan koordinasyon için geniş istişare ortamının sağlanmasını destekleyecektir.

Kentsel Dayanıklılık Ofisinin varlığı; sorun ve veya sorunlara çözüm üretmek için karar verme ve uygulama süreçlerinde problem yaratan dağıtılmış sorumlulukların ve farklı kurumlarda tekrarlanan çalışmaların sebep olduğu kargaşanın ortadan kaldırılması için de gereklidir.

Sistematik ve dinamik bir sürece hizmet etmesi beklenen Kentsel Dayanıklıık Ofisinin kentin özelliklerine uygun olacak biçimde kentin tüm sorunlarını yani akut şok ve kronik streslerini holistik bir bakış açısı ve disiplinler üstü bir çalışma ile bütüncül bir şekilde değerlendirmeye fırsat verecek şekilde doğru tasarlanması, sağlam ve yönetilebilir bir sistem üzerinde, kente özgü, kişi bağımsız ve siyaset üstü olarak oluşturulması önemlidir. (Şekil 10). 


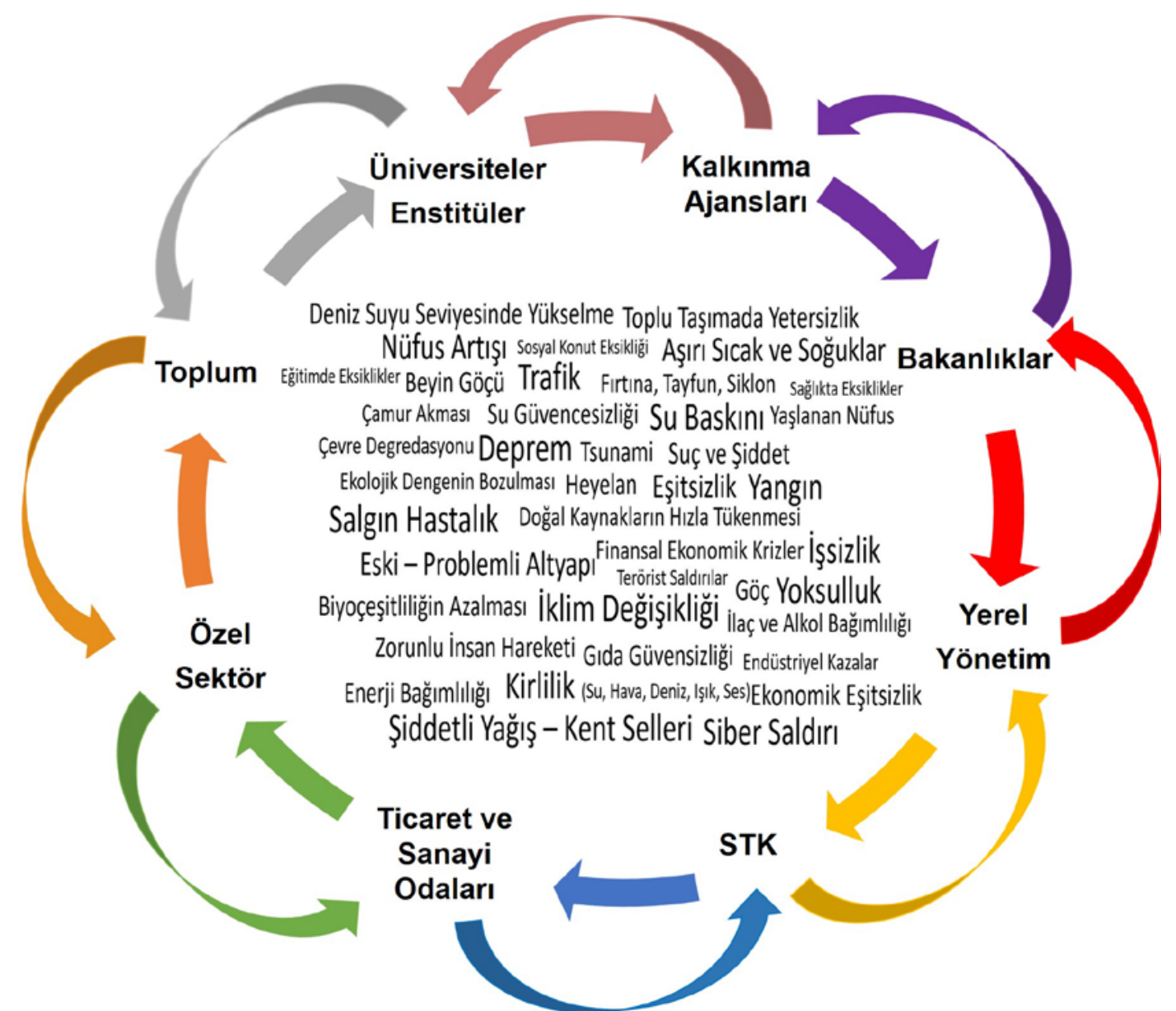

Şekil 10. Kentsel Dayanıklıık Ofisi ile akut şok ve kronik karşısında birlikte çalışma becerisinin kazanılması

Kenti geleceğe taşımak misyonunda oluşturulacak bu platformun yani "Kentsel Dayanıklılık Ofisinin" vizyonu "Sürdürülebilir Dayanıklı Ol" olmalıdır. "Sürdürülebilir Dayanıklı Ol" vizyonunun kent için ortak ve erişebilir bir vizyon olabilmesi için; ofis bünyesindeki tüm paydaşlar tarafından benimsenmesi, içselleştirilmesi gerekmektedir.

Kentsel Dayanıklılık Ofisinin ders al, öngör, azalt, disiplinler üstü çalış, bütüncül yaklaş, birlikte karar ver, sağlam tasarla, yönetilebilir sistemler oluştur, kaynakları doğru yönet, alternatif kaynak yarat, alternatif stratejiler üret, yedek kapasite oluştur, sistemlerin koordinasyonu sağla, adaptif kapasiteni arttır, absorbe etme yeteneğini yükselt, gerektiğinde dönüşebil, devamlılık sağla, ulusal ve uluslararası işbirlikleri oluştur olmak üzere güçlü temel ve stratejik hedefler ile kurgulanması "Sürdürülebilir Dayanıklı Ol" vizyonunun gerçekleşmesi için önemlidir (Şekil 11).

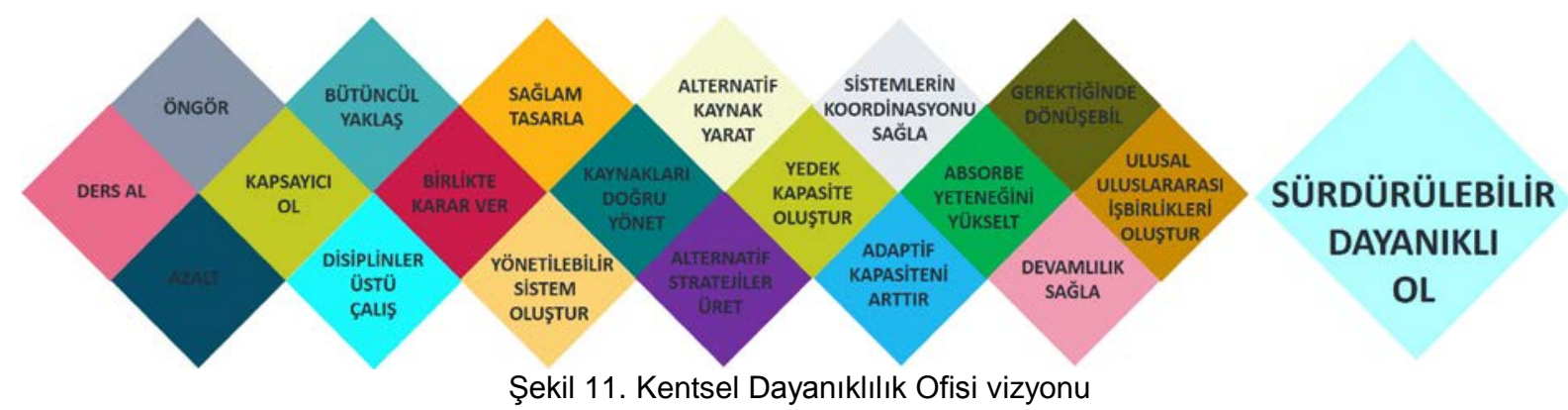




\section{SONUÇ}

Önümüzdeki 30 yıl içinde dünya nüfusunun 4 te 3 ünün kentlerde yaşayacağı öngörülmektedir. Dolayısı ile kentler bizim geleceğimizdir. Geleceğimizi; akut şok ve kronik stresler karşısında güvende ve güçlü tutmak, "Sürdürülebilir Dayanıklılık Yaklaşımı" çerçevesinde kent bütününe kentsel dayanıklılık yeteneğinin kazandırılması ile mümkün kılınabilir. "Kentsel Dayanıklılık Ofisi" tam da bu noktada kurgulanması gereken bir oluşumdur. Bu ofis kapsamında kente ait sorunların ve ilgili çözümlerinin bütüncül olarak, disiplinler üstü çalışma ve holistik bir bakış açısı ile kentin tüm paydaşları ile birlikte değerlendirilmesi, kentsel dayanıklılık ve sürdürülebilir gelişim için doğru yol haritasının hazırlanmasına yardımcı olacaktır.

Değişen, farklılaşan, güçlenen, çeşitlenen, beklenen ve öngörülemeyen akut şok ve kronik stresler karşısında; hazırıklı, güvenli, yaşanabilir dolayısı ile sürdürülebilir kentler için bir an önce yerelde ve küresel de birlikte harekete geçilmesi gerekmektedir. Yoksa tek yaşam alanımız, dünyamız eylemsizliğimizin maliyetini ödeyemeyecek duruma gelecektir.

\section{KAYNAKLAR}

URL-1: 14 Ağustos 2020 tarihinde https://www.worldometers.info/world-population/worldpopulation-by-year/_adresinden alındı.

United Nations (UN1), Department of Economic and Social Affairs. (2019). World Urbanization Prospects, The 2018 Revision. New York: UN DESA. s.10.

World Economic Forum (WEF). (2020). The Global Risks Report 2020. Cenevre: Franco, E.G. Figure1.

Centre for Research on the Epidemiology of Disasters (CRED) \& United Nations for Disaster Risk Reduction (UNDRR). (2020). Human Cost of Disasters. s 6. . 22 Ekim 2020 tarihinde https://www.undrr.org/publication/human-cost-disasters-overview-last-20-years-2000-2019 adresinden alındı.

United Nations (UN2). (2018). The World's Cities in 2018, Data Booklet. New York: UN DESA. S.9.

URL-2: 11 Ağustos 2020 tarihinde https://www.unenvironment.org/explore-topics/resourceefficiency/what-we-do/cities/resource-efficiency-green-economy adresinden alındı.

URL-3: 11 Ağustos 2020 tarihinde https://www.undp.org/content/undp/en/home/sustainabledevelopment-goals/goal-11-sustainable-cities-and-communities.html adresinden alındı.

United Nations Convention to Combat Desertification (UNCCD1). (2019). The land in numbers 2019. Risks and opportunities. Bonn: UNCCD. s.3

UN WATER \& United Nations Educational, Scientific and Cultural Organization (UNESCO). (2019). The United Nations World Water Development Report 2019 Leaving No One Behind. Paris, UNESCO. S.1

United Nations Convention to Combat Desertification (UNCCD2). (2019). The land in numbers 2019. Risks and opportunities. Bonn: UNCCD. s.7 
URL-4: $\quad 11 \quad$ Ağustos $2020 \quad$ tarihinde https://www.un.org/development/desa/en/news/population/world-population-prospects2017.html adresinden alındı.

URL-5: 11 Ağustos 2020 tarihinde https://www.weforum.org/agenda/2016/01/what-are-the10-biggest-global-challenges/ adresinden alındı.

URL-6: $\quad 11 \quad$ Ağustos $2020 \quad$ tarihinde https://www.undp.org/content/undp/en/home/sustainable-development-goals/goal-7affordable-and-clean-energy.html adresinden alındı.

URL-7: 11 Ağustos 2020 tarihinde https://www.worldometers.info/ adresinden alındı.

URL-8: 11 Ağustos 2020 tarihinde https://www.undp.org/content/undp/en/home/sustainabledevelopment-goals/goal-11-sustainable-cities-and-communities.html adresinden alındı.

URL-9: https://www.un.org/sustainabledevelopment/wp-content/uploads/2019/07/14_Why-ItMatters-2020.pdf adresinden alındı.

URL-10: 11 Ağustos 2020 tarihinde https://www.undp.org/sustainable-developmentgoals/goal-14-life-below-water.html adresinden alındı.

Intergovernmental Panel on Climate Change (IPCC). (2019). The Ocean and Cryosphere in a Changing Climate. A Special Report of the Intergovernmental Panel on Climate Change. Section1.4 Changes in the Ocean and Cryosphere. Cenevre: Pörtner, H.O., Roberts, D.C., Masson-Delmotte, V., Zhai, P.,Tignor, M.,Poloczanska, E.,Mintenbeck, K., Alegría, A., Nicolai, M., Okem, A., Petzold, J., Rama, B., Weyer, N.M. s. 1-13.

URL-11: 20 Ağustos 2020 tarihinde https://sdgs.un.org/goals/goal15 adresinden alındı.

URL-12: 20 Ağustos 2020 tarihinde https://sdgs.un.org/goals/goal11 adresinden alındı.

URL-13: 11 Ağustos 2020 tarihinde

https://www.unhcr.org/figures-at-a-glance.html adresinden alındı.

URL-14: 12 Kasım 2020 tarihinde https://covid19.who.int adresinden alındı.

Alexander, D.E. (2013). Resilience and disaster risk reduction: an etymological journey. Natural Hazards and Earth System Sciences Discuss. (1), 1257 - 1284.

Okay, N. \& İlkkaracan, İ. (2018). Toplumsal cinsiyete duyarlı afet risk yönetimi. Resilience, 112.

Gerçek, M., Börekçi, D. Y. (2019) Bireysel yine/yenilenmeyi (rezilyansı/dayanıkıı̆̆ı) destekleyici insan kaynakları yönetimi uygulamalarına ilişkin bir ölçek geliştirme çalışması. Sosyal ve Beşeri Bilimler Araştırmaları Dergisi. Cilt, 20. Sayı, 45.

URL-15 11 Ağustos 2020 tarihinde resilience | Origin and meaning of resilience by Online Etymology Dictionary (etymonline.com)_adresinden alındı.

Folke, C., Carpenter, S., Walker, B., Scheffer, M., Chapin, T. \& Rockstrom, J. (2010). Resilience thinking: Integrating resilience, adaptability and transformability. Ecology and Society, 15(4), pp. 20-28. 
Holling, C. S. (1973). Resilience and Stability of Ecological Systems. Annual Review of Ecology and Systematics. 4(1), 1-23.

United Nations Human Settlements Programme (UN-Habitat 1). (2017). Trends in Urban Resilience 2017. Nairobi. s.4.

Davoudi, S., Shaw, K., Haider, L. J., Quinlan, A. E., Peterson, G. D., Wilkinson, C., Porter, L. (2012). Resilience: a bridging concept or a dead end? "reframing" resilience: challenges for planning theory and practice interacting traps: resilience assessment of a pasture management system in Northern Afghanistan urban resilience: what does it mean in planning practice? resilience as a useful concept for climate change adaptation? the politics of resilience for planning: a cautionary note. Planning Theory \& Practice, 13(2), 299-333.

Holling, C.S. (1996) Engineering resilience versus ecological resilience, in: P.C. Schulze (Ed.) Engineering Within Ecological Constraints, pp. 31-44 (Washington, DC, National Academy Press).

Carpenter, S.R., Westley, F., Turner, G. (2005). Surrogates for resilience of socialecological systems. Ecosystems. 8(8), pp. $941-944$.

United Nations (UN3). (2015). Sendai Framework for Disaster Risk Reduction 2015 - 2030. New York: UN. s.14.

United Nations (UN4). (2016). Addis Ababa Action Agenda - Monitoring commitments and actions - Inaugural Report - Inter-agency Task Force on Financing for Development. New York: UN

URL-16: 11 Ağustos 2020 tarihinde https://www.un.org/sustainabledevelopment/sustainabledevelopment-goals/ adresinden alındı.

Paris Agreement (PARis). Article 7. s.5,6,7. 11 Ağustos 2020 tarihinde https://unfccc.int/files/meetings/paris_nov_2015/application/pdf/paris_agreement_english_.p df adresinden indirildi.

World Humanitarian Summit (WHS). Agenda for Humanity (2015). Restoring Humanity Global Voices Calling For Action - Synthesis of the Consultation Process for the World $\begin{array}{lllll}\text { Humanitarian } & \text { Summit. } & 14 & \text { Ağustos } & 2020\end{array}$ https://synthesisreport.worldhumanitariansummit.org/ adresinden indirildi.

United Nations (UN5). (2017). New Urban Agenda. 14 Ağustos 2020 tarihinde http://habitat3.org/the-new-urban-agenda/ adresinden indirildi.

100 RESILIENT CITIES (100 RC ). (2019). Resilient Cities, Resilient Lives, Learning from the 100 RC network. 28 Aralık tarihinde 100resilientcities.org/wpcontent/uploads/2019/07/100RC-Report-Capstone-PDF.pdf_adresinden indirildi. s.6.

United Nations Human Settlements Programme (UN-Habitat 2). (2018). City Resilience Profiling Tool. 21 Ağustos 2020 tarihinde http://urbanresiliencehub.org/wpcontent/uploads/2018/02/CRPT-Guide.pdf adresinden indirildi. s.13.

ARUP, The Rockefeller Fondation (ARUP, TRF). (2018). City Resilience Index, Understanding and Measuring City Resilience. 25 Ağustos tarihinde 
https://www.arup.com/perspectives/publications/research/section/city-resilience-index adresinden indirildi. s.15.

United Nations Human Settlements Programme (UN-Habitat 3). City Resilience Profiling Tool. 25 Ağustos 2020 tarihinde http://urbanresiliencehub.org/wpcontent/uploads/2018/02/CRPT-Guide.pdf adresinden indirildi. s.23.

Dünya Bankası (DB). (2018). City Strength Resilient Cities Program. 25 Ağustos 2020 tarihinde http://documents1.worldbank.org/curated/en/996471525721935888/pdf/125991WP-P150083-PUBLIC-CityStrength-Guidebook-2018.pdf adresinden indirildi. s.12.

United Nations Human Settlements Programme (UN-Habitat 4). City Resilience Profiling Tool. 25 Ağustos 2020 tarihinde http://urbanresiliencehub.org/wpcontent/uploads/2018/02/CRPT-Guide.pdf adresinden indirildi. s.18. 